\author{
UNIVERSIDADE DE SÃO PAULO \\ INSTITUTO DE PSICOLOGIA \\ CURSO DE POS-GRADUAÇAO EM PSICOLOGIA
}

\title{
IMAGENS MENTAIS EM PSICOTERAPIA: \\ Estudo empirico sobre sua eficácia e a importância da atitude e da habilidade do cliente em manejá-las
}

Candidato(a): NICOLAU TADEU ARCARO

Orientador(a): Professora Associada Nilce Pinheiro Mcjias

Tese apresentada ao Instituto de Psicologia, Universidade de São Paulo, como parte dos requisitos para obtenção do grau de Doutor em Psicologia - área de concentraçåo PSICOLOGLA Clínica

\section{COMISSÃO JULGADORA}

Professor Doutor Stanley Krippuer Professora Doutora Vera Engler Cury Professor Titular Arno Engelmann

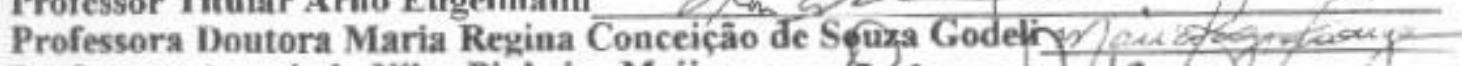
Professora Associada Nilec Pinheiro Mejias

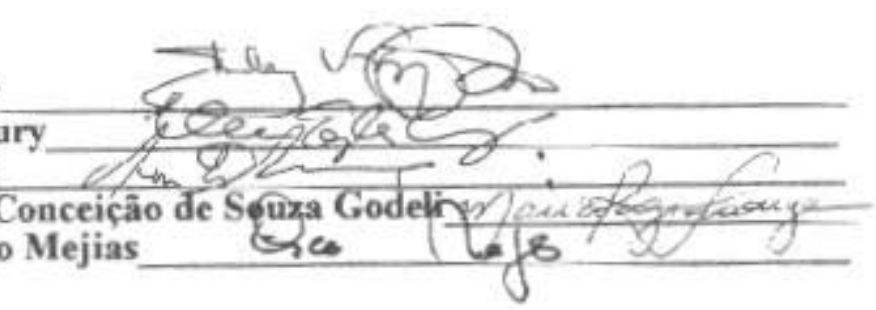

Defesa - 1997 
É lutando contra o inelutável que o homem, apesar do fracasso, mostra o melhor de si.

Dedico este trabalho a todos aqueles que, mesmo sabendo-se perdedores de antemão, não fogem das lutas em que precisam se bater.

Em particular, ele é dedicado a Benedicto Ferri de Barros e a José Severo de Camargo Pereira (em memória), dois verdadeiros expoentes do mundo intelectual e também importantes modelos de vida para mim. 


\section{AGRADECIMENTOS}

* À Dra. Nilce Pinheiro Mejias, que de maneira dedicada e competente acompanhou as atividades de pesquisa que realizei desde os tempos de graduação até o presente doutorado.

* Ao colega e amigo Paulo Eliezer Ferri de Barros, por me auxiliar na estruturação do tratamento que fez parte desta investigação, colaborar na revisão do relato da mesma, ceder-me equipamento eletrônico necessário para a filmagem dos atendimentos que realizei e, finalmente, pelo grande apoio emocional que me deu em todas as fases deste projeto.

* Ao Dr. Arno Engelmann, por ter-me fornecido material bibliográfico e acompanhado a elaboração final da parte teórica deste trabalho.

* Ao Dr. Stanley Krippner, pelo fornecimento de material bibliográfico e pela cuidadosa revisão que fez deste trabalho antes de sua apresentação aos demais membros da banca examinadora.

* Ao Dr. José Severo de Camargo Pereira (em memória), por ter-me ajudado no planejamento experimental e na elaboração da estrutura básica da análise estatística deste estudo, bem como por acompanhar a adaptação dos testes que fizeram parte do mesmo.

* Ao CNPq e à FAPESP, que forneceram recursos financeiros que facilitaram bastante a realização desta pesquisa.

* Aos departamentos de Psicologia Clínica e de Psicologia Experimental do I.P.U.S.P., que me permitiram utilizar suas instalações físicas para atendimento e avaliação dos participantes deste trabalho.

* Aos colegas e amigos Aceli de Assis Magalhães, Liomar Quinto de Andrade e Ricardo Franklin Ferreira, por terem colaborado em parte da análise de dados deste estudo.

* Ao colega e amigo Elias Boainain Jr., por ter-me fornecido informações de grande valia para a parte teórica desta investigação.

* Às Doutoras Eda Terezinha de Oliveira Tassara e Regina C. de Souza Godeli, bem como ao Dr. Walter Trinca, por me fornecerem pareceres importantes sobre o projeto inicial desta pesquisa.

* Aos Doutores César Ades e Mário Guidi por me auxiliarem com questões técnicas da filmagem do tratamento envolvido neste trabalho.

* À estatística Mariana Cúri, por sua contribuição na realização e na revisão da análise estatística deste estudo.

* À estatística Vânia Nilson Arcaro, por colaborar na revisão da análise estatística desta investigação. 
* A Suziney Cavalcante de Albuquerque, por seu auxílio nas etapas de avaliação e filmagem desta pesquisa.

* A Ana Cristina Gandara Lunardi e Maria Regina Monteiro, pelos trabalhos de filmagem que realizaram.

* A Marília Ribeiro Frias, por me auxiliar nos contatos com os participantes desta investigação.

* A todos os colegas professores que, gentilmente, me permitiram visitar suas salas de aula para divulgar meu trabalho, de modo a conseguir participantes para o mesmo.

* À Profa. Mônica Helena Tieppo Alves Gianfaldoni, que além de consentir na divulgação de minha pesquisa em suas salas de aula, permitiu que uma delas constituísse meu grupo de controle.

* A Virgínia Maria Ferraz de Castro, pela valiosa ajuda em meus contatos via Internet.

* A todos os integrantes do tratamento e do grupo de controle que fizeram parte desta investigação, sem os quais não teria sido possível a realização da mesma.

* A todos os amigos e colegas que, com simpatia e entusiasmo, incentivaram este trabalho.

* A Regina, pelo companheirismo, entusiasmo e auxílio na fase de conclusão desta pesquisa. 


\section{ÍNDICE}

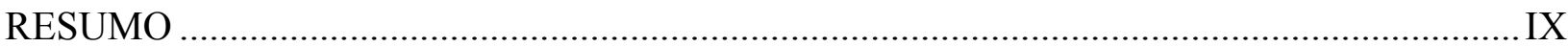

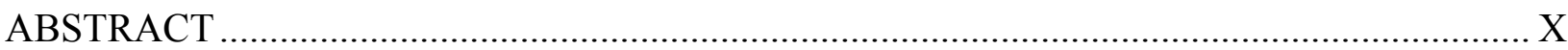

RÉSUMÉ

$$
\text { *** INTRODUÇÃO *** }
$$

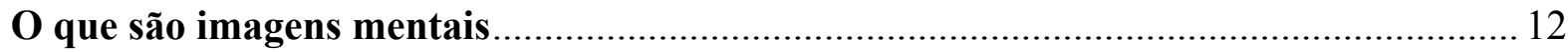

A utilização de imagens mentais da antigüidade aos nossos dias ................................ 14

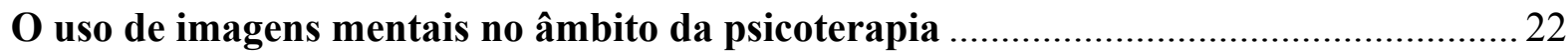

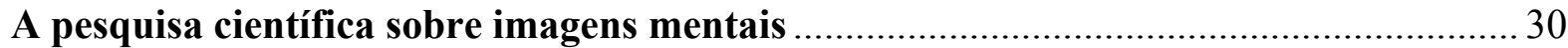

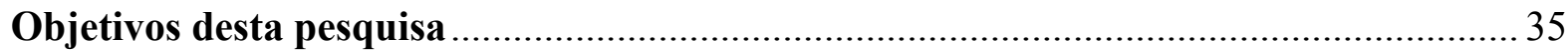

$$
* * * \quad M E ́ T O D O \quad * * *
$$

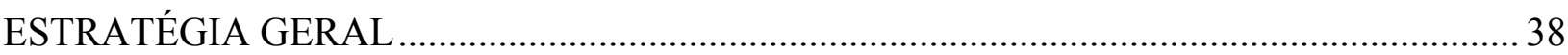

POPULAÇÃO ALVO, CLIENTELA E GRUPO DE CONTROLE ............................................ 39

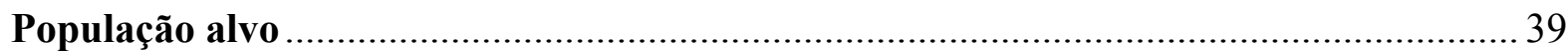

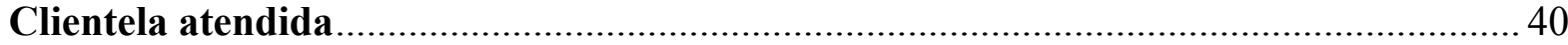

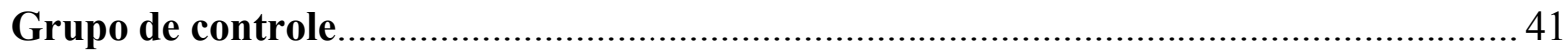

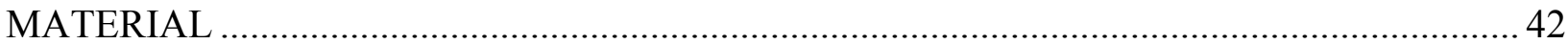

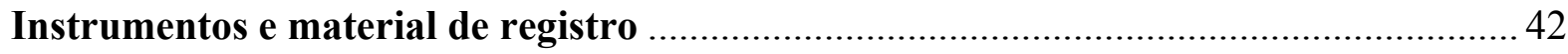

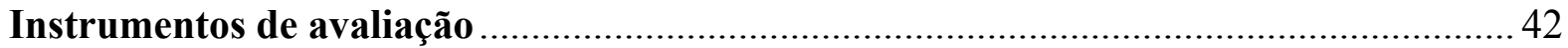

Avaliação da ansiedade ao realizar provas ou exames..................................................... 42

Avaliação da atitude frente às imagens mentais................................................................ 43

Avaliação da vivacidade das imagens mentais ................................................................. 43

Avaliação do controle sobre imagens mentais ................................................................... 43 


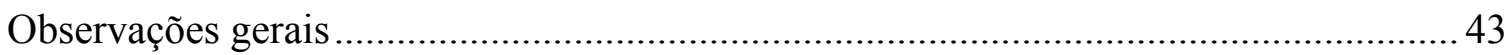

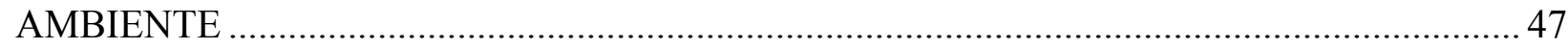

SELEÇÃO DA CLIENTELA E DO GRUPO DE CONTROLE .............................................. 48

Contatos com a população alvo e obtenção da clientela .............................................. 48

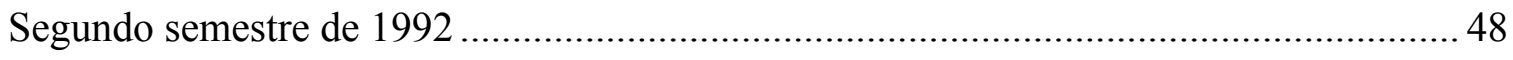

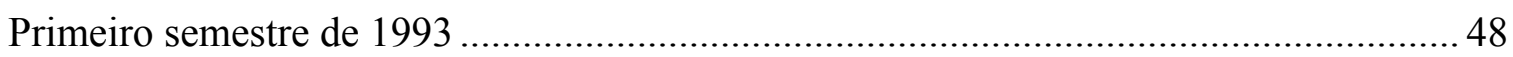

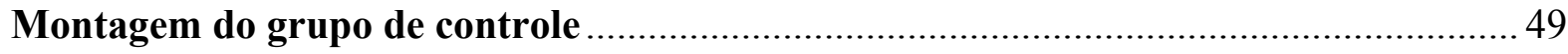

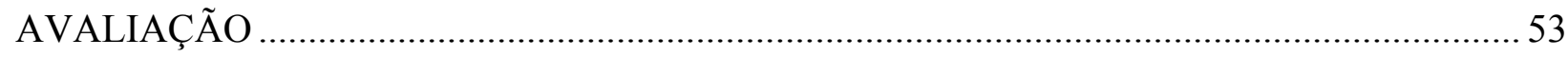

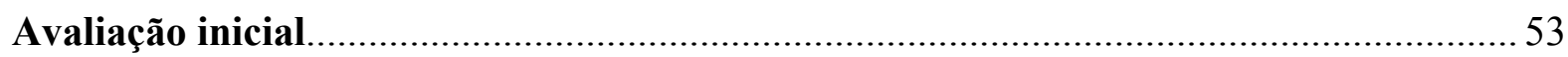

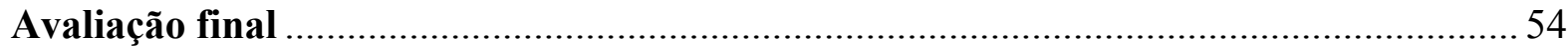

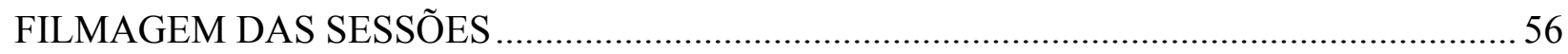

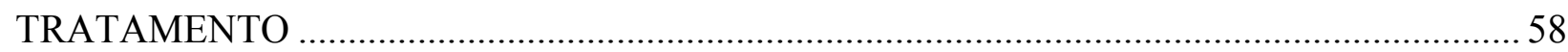

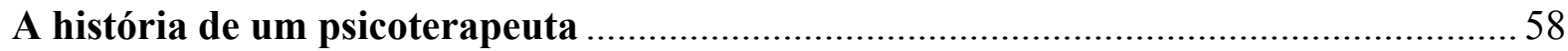

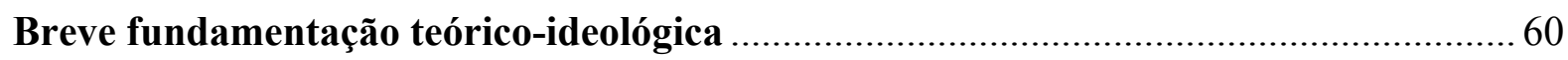

A atividade psicoterapêutica visa o crescimento psicológico ......................................... 61

Diversas formas de intervenção podem levar ao crescimento psíquico........................... 62

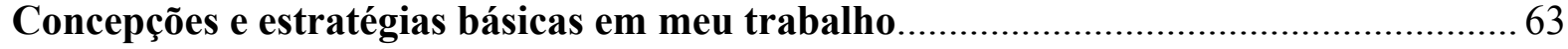

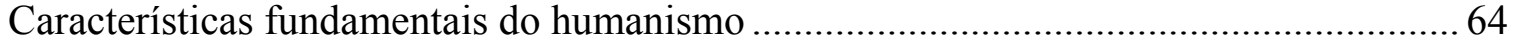

Processos supraconscientes e estados alterados de consciência....................................... 70

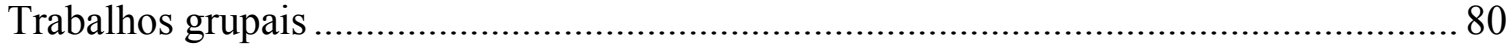

Breve histórico e características genéricas .......................................................... 80

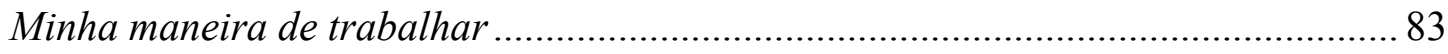

Alguns aspectos mais específicos de minha atuação ....................................................... 86

Particularidades do tratamento que realizei ............................................................ 87

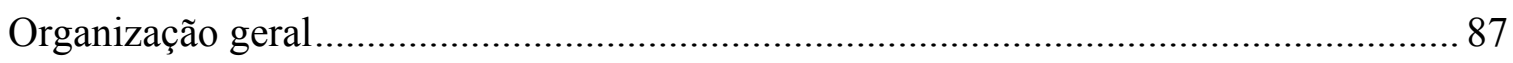

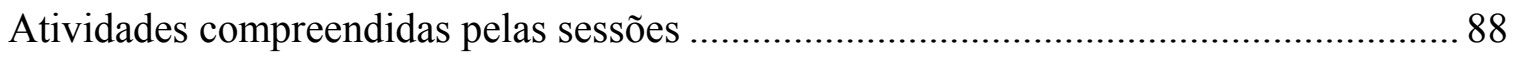

Exercícios terapêuticos que utilizei sistematicamente ...................................................... 90

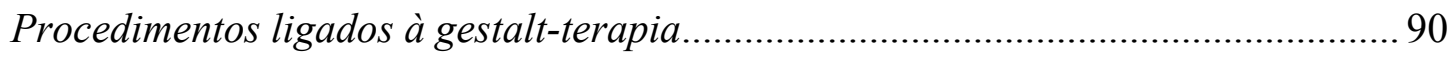

Exercícios de fantasia dirigida ................................................................................ 91

$$
\text { *** RESULTADOS *** }
$$


Avaliação do sucesso do tratamento e suas relações com o comportamento frente a imagens.

Avaliação de influências do tratamento sobre o

comportamento frente a imagens.

ANÁLISE ESTATÍSTICA

Redução da medida de ansiedade e suas relações com as de comportamento frente a imagens.

Verificações globais 102

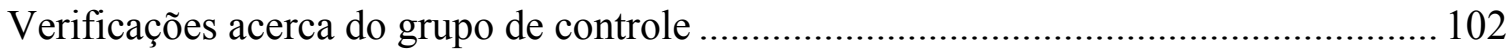

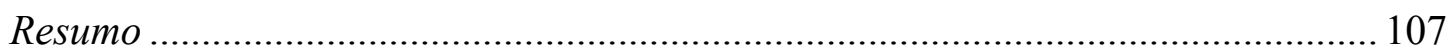

Verificações acerca da clientela sem trabalho paralelo................................................ 108

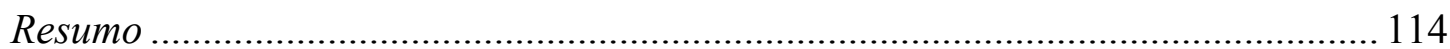

Verificações acerca da clientela com trabalho paralelo ................................................... 114

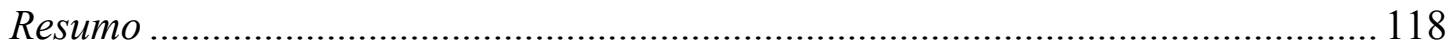

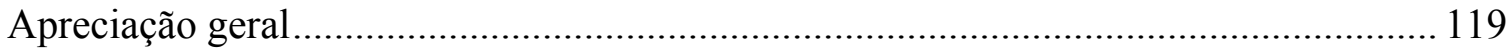

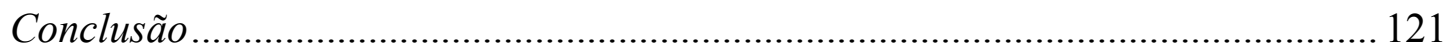

Efeitos do tratamento sobre as medidas de comportamento

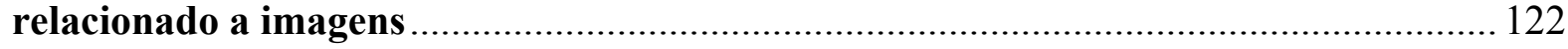

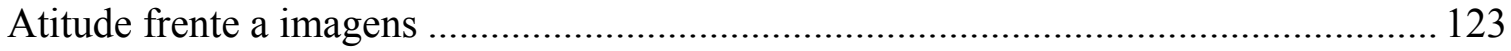

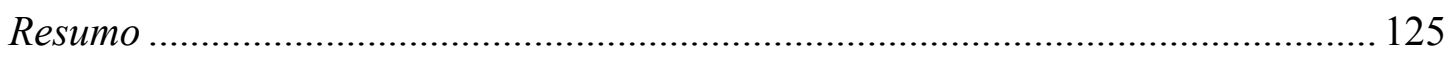

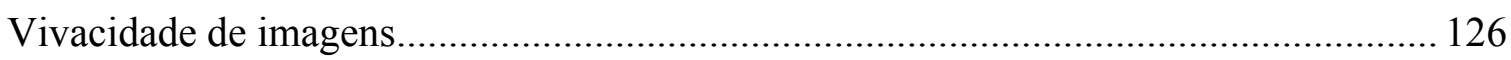

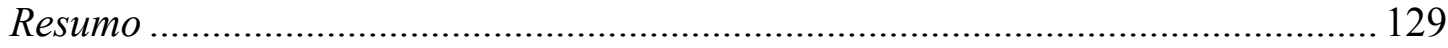

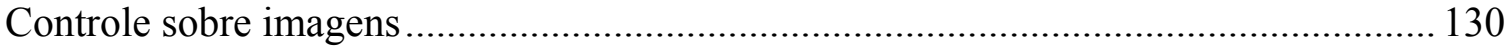

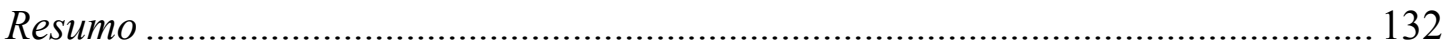

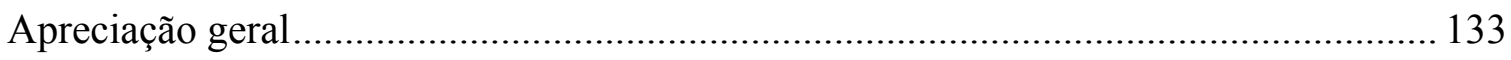

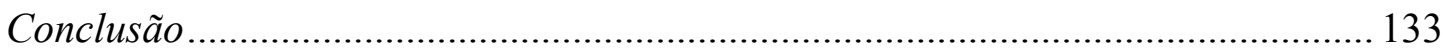

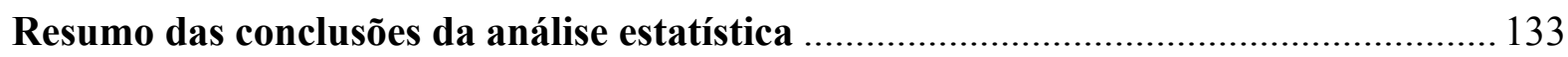

DISCUSSÃO GERAL DOS RESULTADOS ..................................................................... 135

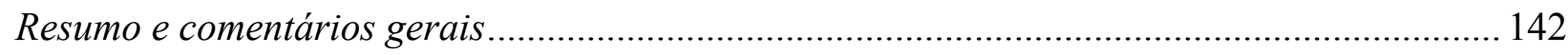

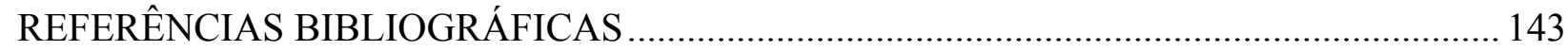

APÊNDICE 1: Análise da avaliação feita pela clientela sobre seus progressos no tratamento.. 155

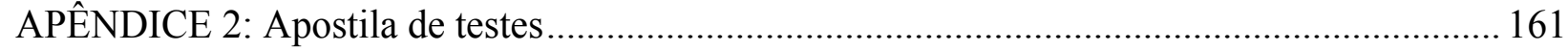

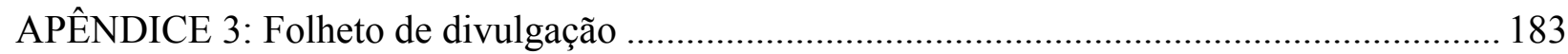


ARCARO, N. T. Imagens mentais em psicoterapia: Estudo empírico sobre sua eficácia e a importância da atitude e da habilidade do cliente em manejá-las. São Paulo, 1997, 118 p., Tese de Doutorado, Instituto de Psicologia da Universidade de São Paulo.

\section{RESUMO}

O objetivo desta investigação foi avaliar a eficácia de uma estratégia de psicoterapia breve e grupal baseada em exercícios de fantasia dirigida, e se tal eficácia estava relacionada à atitude das pessoas atendidas frente à imaginação, à vivacidade de suas imagens mentais e ao controle que tinham sobre estas. Os exercícios imagéticos foram realizados com o intuito de promover estados levemente alterados de consciência que, por sua vez, permitissem a ativação de potenciais psicológicos supraconscientes. Isso com o propósito de auxiliar estudantes universitários a superarem problemas de ansiedade em situações de prova e exame. As medidas de um grupo experimental $(n=32)$ em escalas de ansiedade e atitude frente à imaginação, bem como de vivacidade e controle de imagens mentais, tomadas antes e após a realização do tratamento psicoterápico, foram comparadas às de um grupo de controle $(\mathrm{n}=50)$. E a análise estatística dos resultados obtidos forneceu indícios claros do sucesso da terapêutica empregada, mas não da relação entre esse sucesso e as variáveis ligadas a imagens mentais que foram levadas em conta. 
ARCARO, N. T. Mental imagery in psychotherapy: An empirical investigation on their efficacy and the importance of clients' attitude and skill in handling them. São Paulo, 1997, 118 pp., Doctoral Dissertation, Institute of Psychology of University of São Paulo.

\begin{abstract}
The objective of this investigation was to evaluate the efficacy of brief group psychotherapy based on guided imagery, and if this efficacy was related to clients' attitude toward imagination and clients' imagery vividness and control. Guided imagery, aimed to promote slightly altered states of consciousness, were used with the purpose of activating supra conscious psychological potentials to help undergraduates with test anxiety problems. Measures of an experimental group $(n=32)$ on test anxiety, attitude toward imagination, imagery vividness and control scales, taken before and after the therapeutic strategy's implementation, were compared with measures of a control group $(n=50)$. Statistical analysis indicated the success of the therapeutic method employed but no clear connections between this success and the imagery related variables considered.
\end{abstract}


ARCARO, N. T. Images mentaux en psychotérapie: Estude empirique sur ça efficacité et l'importance de l'attitude et de l'habilité de les clients en les employées. São Paulo, 1997, 118 p., Thèse de Doctorat, Institut de Psychologie de la Université de São Paulo.

\section{RESUME}

L'objectif de cette investigation a été avalier l'efficacité d'une form de psichothérapie bref et grupal foundamentée sur les exercises de fantasie dirigée, et se cette efficacité a été relacionée a l'attitude des participants vers l'imagination, a la vivacité de leurs images mentaux et a le contrôle qu'ils ont eu sur cette la. Les exercises avec images ont été realizés avec l'intention de générer des états de conscience légèrement alterés qu'ils permetaient, a cette fois, l'activation des potentiaux psychologiques sur-conscients. Ça a été fait avec le propos d'auxiliaire des étudiants universitaires a dépasser des problèmes d'anxiété en situations de examens. Les mesures d'un group expérimental $(n=32)$ en tests d'anxiété, d'attitude vers l'imagination, vivacité et contrôle d'images, collectées avant et après le traitement psychotérapique, ont été comparée avec les mesures d'un group de contrôle $(n=50)$. L'analyse statistique de les résultats obtenus ont donée indications claires de le succès de la thérapeutique employée, mais pas de la relation entre ce succès e les variables liées a l'images mentaux qui ont été considéretes. 
I N T R O D U Ç Ã O 


\section{INTRODUÇÃO}

\section{O que são imagens mentais}

Imagine-se subindo por uma trilha na encosta de uma colina agreste numa noite de luar. A noite é clara, o céu estrelado, uma brisa leve sopra refrescando o ambiente. Você pode ouvir o farfalhar das folhas da vegetação, o barulho dos grilos e dos pássaros noturnos, e sentir a terra macia sob seus pés. Quando chegar no alto você vai ver, mais ao longe, a silhueta de uma pessoa sentada próxima a uma fogueira. Você vai se aproximar, alimentar o fogo com gravetos que existem ao redor, e observar essa pessoa ao clarão das chamas...

Ou então imagine que seu corpo vai ficando muito, muito leve, tão leve que começa a flutuar. Você vai-se elevando cada vez mais alto, abandona a Terra e inicia uma viagem rumo ao sol. Você vai passando pelos planetas vizinhos, tendo as estrelas como pano de fundo. Sua sensação é de grande liberdade e bem-estar, vagando de maneira solta pela imensidão do espaço. Imagine agora que você se aproxima do sol. E que ele tem uma luz bastante bonita, que banha seu corpo com um toque morno e suave. Conforme você sente essa luz sua disposição melhora cada vez mais. Mergulhe no sol, imergindo em sua luz fulgurante e agradável...

E agora imagine que, levando-se as pessoas a fantasiarem situações bonitas e agradáveis como essas, pode-se estar contribuindo, e muito, para seu crescimento psicológico e a resolução de seus problemas. Olhando dessa forma talvez não seja fácil acreditar. É incrível que algo à primeira vista tão simples possa consistir num poderoso recurso de intervenção psicológica e médica. Mas isto é a mais completa verdade.

Essas histórias constituem um tipo de exercício terapêutico chamado 'fantasia dirigida', que é empregado há várias décadas por diversas abordagens psicoterapêuticas. Consiste, basicamente, em uma seqüência de imagens mentais interligadas, que formam uma viagem ou enredo que se induz as pessoas a imaginarem ${ }^{1}$.

As imagens mentais, os principais elementos de experiências como estas, são aquelas que também compõem fenômenos como os sonhos, devaneios, memórias sensoriais e de teor emotivo, vivências hipnagógicas e alucinações². São representações internas de

1 No decorrer deste trabalho, utilizarei a expressão 'fantasia dirigida' no mesmo sentido que a expressão inglesa 'guided imagery'. De acordo com Witmer e Young (1985), esta expressão remete a um dos dois tipos genéricos de exercícios para a produção de imagens em estado de vigília. Ao outro se referem como 'directed imagery'. A diferença entre ambos está em que, enquanto o intuito do último é dirigir completamente as imagens que serão produzidas, o do primeiro é o de despertar certos tipos de imagens espontâneas. Isso é feito apresentando-se uma situação semi-estruturada para o indivíduo imaginar, de modo que, para realizar a tarefa, ele precisa preencher as lacunas das instruções com os tipos de imagens espontâneas que se deseja que ele evoque.

2 A rigor, a maioria dos fenômenos que mencionei acima não é composta somente por imagens mentais, mas também por outras experiências psíquicas como o pensamento abstrato. Apesar disso, como essas imagens geralmente são seus componentes fundamentais, os que lhes dão forma e consistência, o mais comum é se referir a eles como constituídos 
aspecto concreto ${ }^{3}$, ou seja, são semelhantes a experiências sensoriais mas ocorrem na ausência das condições estimulatórias que genuinamente provocariam estas últimas (Richardson, 1969, 1983). Por exemplo, se observarmos uma casa existente num lugar por onde passamos, isto terá sido uma experiência verdadeiramente sensorial, já que foi produzida por um estímulo visual, ou seja, a casa que vimos. Contudo, se a imagem de uma casa aparecer num sonho ou a evocarmos de memória, ela será uma imagem mental, pois o estímulo visual não estará presente.

É comum pensar nas imagens desse gênero como sendo apenas visuais. Boa parte da literatura científica, inclusive, está predominantemente voltada para estas últimas (cf. Pinker \& Kosslyn, 1983; Richardson, 1983). Não obstante, as imagens visuais, o que especificamente se chama de visualização, são apenas um dos tipos de imagens. Assim como temos a capacidade de representar coisas visualmente dentro de nós, possuímos a de fazê-lo com base em todas as outras modalidades sensoriais (cf. Bandler \& Grinder, 1982; Lusebrink, 1990; Richardson, 1969, 1983). Em nosso interior, podemos não só ver os mais diversos seres, objetos e cenários, como também ouvir seus sons, sentir seu toque, seu cheiro e seu gosto. E ainda somos dotados da faculdade de gerar representações de configuração proprioceptiva, ligadas a sensações viscerais, bem como cinestésica, referentes à posição, ao peso e ao movimento corporal.

Além disso, segundo estudiosos como Richarson (1969; 1983), possuímos a capacidade de formar imagens mentais de estados afetivos. Neste caso, é claro, não se pode tomar qualquer emoção relacionada a um processo imaginário como uma imagem desse teor. Ela só existe quando acontece uma representação imaginária de uma emoção, e não quando se vivencia uma emoção genuína despertada por algum conteúdo da imaginação. Se uma pessoa estiver imaginando a alegria de alguém, ou lembrando de sua própria alegria frente a determinada situação, isso será uma imagem. Por outro lado, se evocar a imagem de um acontecimento passado e ficar contente com isso, ou imaginar uma situação aversiva e ficar irritada ou amedrontada com ela, tais emoções não serão, em si, imagens, mas sim estados afetivos reais provocados por estas últimas.

É bom enfatizar que estou adotando a concepção tradicional de imagens mentais, que se refere estritamente a representações internas com características essencialmente concretas (cf. Pinker \& Kosslyn, 1983; Richardson, 1983) ou, conforme dizem certos autores (e.g. Lusebrink, 1990; Richardson, 1969, 1983), representações de teor 'quasesensorial' ou 'quase-perceptivo'. E que, segundo essa concepção, elas apresentam um caráter fenomênico: muito embora sua maioria talvez ocorra de maneira inconsciente - há estudiosos que defendem a idéia de que vivenciamos um fluxo constante de imagens em nosso interior, a

simplesmente por elas. A única exceção que conheço a esse respeito, ou seja, o único caso em que a constituição básica dos fenômenos em questão pode deixar de se calcar em imagens mentais, é quando estruturam-se fundamentalmente a partir do tipo de experiência que Richardson (1983) rotula como "apenas saber", ou "sentimento de saber" (p.10). Uma pessoa pode imaginar um cenário ou enredo através de representações internas concretas, ou pode apenas saber, sentir que sabe, ter um conhecimento intuitivo de como é esse cenário ou enredo. Há autores que crêem que experiências como esta, em que imagens concretas não são percebidas, envolvem tais imagens de maneira subjacente, inconsciente (cf. Rollins, 1989). Entretanto, esta é uma alegação teórica. De um ponto de vista fenomenológico, tudo o que se tem é a vivência de 'apenas saber'. Por exemplo, um participante de um programa de treinamento que conduzi disse, após determinado exercício de fantasia dirigida, que este não lhe despertara nenhuma imagem mental. Contudo, sabia ter-se imaginado preso em uma jaula com algemas às costas. Dessa forma, independente de qualquer imagem perceptível, ele havia estruturado uma cena bastante palpável e nítida, o que inclusive tem tanta utilidade para o trabalho psicoterápico quanto experiências de aspecto mais concreto.

3 A palavra 'concreto' está aqui sendo utilizada em sua acepção filosófica. De acordo como o Novo dicionário da língua portuguesa (Ferreira, 1986), em tal acepção a referida palavra diz respeito a "coisa ou representação que se apresenta de modo completo, tal como lhe é próprio apresentar-se na sua realidade existencial". 
maior parte do qual inconscientemente - elas são sempre, ao menos, potencialmente perceptíveis de maneira consciente (Richardson, 1983) ${ }^{4}$.

Sendo assim, quando falo em imagem mental não estou querendo designar, como o fazem certos autores, um suposto mecanismo interior que apresenta efeitos vividos conscientemente mas não pode, em si, ser vivido de tal maneira. Este é o caso, por exemplo, de uma série de pesquisadores cognitivistas que postulam que o aspecto experiencial das imagens é, quando muito, um epifenômeno, e não parte de seu caráter essencial ${ }^{\mathbf{5}}$ (cf. Pinker \& Kosslyn, 1983; Richardson, 1983). E também o de autores que se referem a idéias como imagem corporal, imagens parentais internalizadas ${ }^{6}$, etc.. Mais uma vez recorrendo a Richardson (1983), pode-se dizer que estudiosos como esses estão se referindo a imagens como sendo constructos teóricos, elementos de uma teoria que explicam certas características da experiência concreta, e não como sendo acontecimentos fenomenais, passíveis de serem diretamente experienciados.

Além do mais, ficam excluídas as imagens verbais, de teor puramente semântico (analógico, metafórico). Neste caso, apenas pode-se considerar como imagem mental uma simbolização interna concreta, de aspecto sensorial, de alguma coisa concreta ou abstrata. E não é o seu aspecto simbólico que faz dessa experiência uma imagem mental, e sim seu caráter concreto. Analogias ou simbolizações de caráter abstrato, puramente verbal estão, portanto, fora do âmbito de minha definição.

Da mesma forma, quando falamos numa imagem que temos de alguém, ou de uma determinada situação, se ela for uma imagem concreta que guardamos na memória, esta será uma imagem mental. Mas não o será se estivermos nos referindo à opinião que fazemos desse alguém ou dessa situação.

\section{A utilização de imagens mentais da antigüidade aos nossos dias}

Tendo explicado o que neste trabalho considero como imagens mentais, passarei agora a descrever suas utilizações. Tentarei discorrer de maneira abrangente a respeito do assunto, mostrando inclusive diversas formas assumidas pelas estratégias imagéticas e diversos propósitos que as nortearam ao longo da história da humanidade7. Isso com vistas a proporcionar uma visão razoavelmente ampla sobre o potencial e a versatilidade de tais estratégias.

Longe de restringir-se apenas à psicologia, o interesse pelas imagens mentais e sua utilização tem estado presente em todas as etapas do desenvolvimento cultural humano.

4 Evidentemente, estou aqui me referindo a um potencial genérico das imagens desse teor, sem levar em conta questões circunstanciais e de ordem prática. Em termos concretos, é claro que, por uma série de fatores, que vão desde bloqueios emocionais até simplesmente a falta de motivação ou tempo para observar, não é possível que ninguém esteja ciente de todas as imagens que produz.

5 Ou seja, embora as imagens muitas vezes apresentem um correlato vivencial, não é nisto em que consistem basicamente. $\mathrm{Na}$ realidade, elas são fundamentalmente estruturas internas que imprimem certas características no comportamento e na percepção das pessoas, entre as quais a de, vez por outra, se experienciar seu correlato vivencial.

6 No que toca estas últimas é bom acrescentar que, embora estejam basicamente relacionadas a uma noção primitiva, um conceito arcaico que alguém possui da mãe ou do pai, há autores que também se referem a elas enquanto imagens internas concretas que simbolizam essa noção a respeito dos pais (como a imagem de uma mulher ou de um homem que apareça num sonho). Portanto, em seu sentido básico não são o que estou aqui chamando imagens mentais, mas no segundo dos sentidos que expliquei o são.

7 O leitor que desejar maiores detalhes sobre a história dos trabalhos com imagens poderá encontrar grande profusão deles em Samuels e Samuels (1975), que foi a principal fonte de consulta que utilizei para realizar esta narração. Além disso, no que concerne a alguns dos assuntos específicos apresentados adiante, baseei-me também em duas outras obras: algumas informações referentes ao uso de imagens mentais na pré-história foram extraídas de "A pintura" (1996), e outras, sobre medicina e incubação de sonhos na Grécia Antiga, de Groesbeck (1983). 
Esse interesse estendeu-se, ao longo de milênios, sobre as mais variadas áreas de atividade, abarcando desde a filosofia e a religião, até a medicina, a agricultura, a meteorologia e, apenas mais recentemente, a psicologia.

Inicialmente, a preocupação com elas provavelmente decorreu do fato de serem vistas como relacionadas ao mundo espiritual. Isso era particularmente importante para o homem antigo, pois sua compreensão das coisas era eminentemente espiritualista.

Supõe-se que, a princípio, esse homem sequer fizesse uma diferenciação clara entre o material e o espiritual. Percebia a realidade como uma mistura dos dois, sentindo-se igualmente próximo de ambos. Numa tal época, provavelmente, imagens interiores entremeavam-se de maneira relativamente indistinta à percepção do mundo exterior, para comporem o panorama de um universo mágico, onde aspectos físicos e espirituais apareciam visivelmente associados ${ }^{8}$.

Com o passar do tempo, porém, as pessoas foram cada vez menos vivenciando esse mundo de magia, ficando mais e mais limitadas à percepção das coisas materiais. Então começaram a estruturar uma série de práticas de teor místico-religioso, visando retomarem o contato com o universo dos espíritos.

Tais práticas estavam muitas vezes associadas à indução deliberada de estados alterados de consciência, como os meditativos, de transe alucinatório ou êxtase, em que imagens mentais eram evocadas. E envolviam também a utilização de sonhos e visões que aconteciam naturalmente.

Julgava-se que as sensações e imagens que ocorriam em situações como essas fossem a possibilidade que restara ao homem de acesso à dimensão espiritual. Tal dimensão, apesar de já percebida de maneira relativamente diferenciada da realidade material, continuava a ser vista e sentida como a origem desta última, advindo daí sua importância. E uma vez que o contato com ela ocorria predominantemente através das imagens mentais e das sensações que as acompanhavam, estas eram, muitas vezes, consideradas mais importantes que a percepção objetiva.

Exemplos disso são as idéias apregoadas no ocidente em tempos antigos por filósofos herméticos e platônicos, e as propagadas no oriente há já muitos séculos por sufis, iogues e budistas. Segundo elas, a matéria é a manifestação do espírito central do universo, ao qual se pode ter acesso meditando e mentalizando imagens. No hermetismo afirmava-se, inclusive, que concentrar-se nessas imagens por certo tempo podia modificar o universo físico, tal era a supremacia que se julgava que elas tinham sobre universo objetivo.

Como se pode perceber, a fé no poder das imagens tanto de vigília como de sonhos era bastante intensa na antigüidade. Inspiradas nela, muitas culturas engendraram, com os mais variados propósitos, diversas formas de utilizar tais imagens. É possível que as mais antigas delas já tenham sido empregadas há trinta mil anos, por nossos ancestrais das cavernas. Os indicativos a esse respeito ligam-se às estatuetas por eles esculpidas e às pinturas que fizeram nas paredes de suas grutas. Grande parte das primeiras eram figuras de mulheres, que supostamente simbolizavam deusas da fertilidade, ou de animais. E as últimas em geral retratavam pessoas, mãos humanas, sinais geométricos e, principalmente, animais, tanto reais como fantásticos.

Tanto as estatuetas como as pinturas consistiam, predominantemente, em exteriorizações de imagens mentais, o que revela que estas eram, por algum motivo, alvo de uma preocupação significativa. Presume-se que esse motivo relacionava-se, também neste

8 Uma possível explicação psicológica para esse fenômeno é a de que, nos primórdios da humanidade, sendo a consciência dos indivíduos ainda muito menos desenvolvida que atualmente, os processos inconscientes nela se imiscuíam com mais intensidade e freqüência do que em nossos dias. $\mathrm{E}$ isso a ponto de ser difícil diferenciar imagens associadas a esses processos, vistas como espirituais, da percepção genuinamente sensorial. 
caso, à busca de contato com o espiritual. Há estudiosos que acreditam que houvesse cavernas utilizadas como espaço ritual para tanto, e que as pessoas, enquanto vivenciavam experiências imagéticas em tais lugares, as registravam nas paredes. Essas paredes, por sua vez, eram percebidas como uma espécie de véu entre a realidade objetiva e a espiritual, de modo que desenhar figuras nelas era lidar com o intercâmbio entre tais realidades.

E conquanto não haja evidências cabais que o confirmem, é provável que a procura de um tal intercâmbio não fosse desinteressada. Há indícios de que as imagens que descrevi acima estivessem envolvidas em práticas mágicas com propósitos como curar doenças, assegurar a fecundidade, promover o sucesso na caça ou na guerra, etc.. Certos desses indícios dão inclusive idéia de algumas das formas que essas práticas eventualmente assumiam. Por exemplo, foram encontradas marcas de lanças em desenhos de bandos de animais, o que indica a possibilidade de que tais desenhos fossem utilizados em rituais propiciatórios da caça: as pessoas os atacavam com suas lanças, e isso provavelmente era entendido como um encantamento com o poder de aumentar o êxito das caçadas.

Magia à parte, esse pode ter sido um dos primeiros casos em que se usou imagens mentais, nessa situação intermediadas por expressão gráfica, para o ensaio de uma determinada atividade. O homem pré-histórico, com isso, devia realmente aumentar suas chances de sucesso no abate de animais, pois tinha oportunidade de evocar sentimentos de força e confiança, adequados para a tarefa que iria enfrentar. Ademais, esses rituais também deviam servir para aperfeiçoar suas habilidades de caçador, fosse através da prática direta das mesmas, seja através da observação de outra pessoa as exercendo.

Abordando agora uma outra faceta da questão em pauta, há uma grande chance de que, já naquela época, as tribos tivessem pessoas específicas que administravam atividades consideradas mágicas, ou seja, xamãs. Embora talvez não seja de fato assim tão antigo, sabese que o xamanismo remonta à pré-história, tendo sido provavelmente a primeira forma mais organizada de administração de assuntos espirituais. Suas práticas perduram até nossos dias, ocorrendo generalizadamente em diversos povos tecnologicamente primitivos e em vários segmentos das sociedades ditas modernas. Usualmente, um indivíduo era e ainda é escolhido para ser xamã devido a sua grande capacidade de atingir estados alterados de consciência. Nesses estados ele tem visões, isto é, evoca imagens mentais muito vívidas, bem como sensações incomuns.

Tal capacidade é valorizada devido à crença, também presente no xamanismo, de que todos os acontecimentos resultam da ação do espiritual, e de que as imagens mentais, bem como as sensações invulgares presentes nos estados alterados de consciência, são os principais meios de contatar deuses e outros espíritos. Por causa desse seu dom, o xamã é considerado o principal mediador entre os homens e tais entidades. E sendo estas as responsáveis por tudo o que acontece, ele assume várias funções como sacerdote, médico, psicoterapeuta e adivinho.

Seu objetivo não só é o de ter contato direto com o divino, mas também o de propiciá-lo às outras pessoas. Isso é obtido principalmente através dos estados alterados que ele atinge e induz nos demais. Tal indução é catalisada tanto pelo carisma pessoal do xamã, e pelo valor simbólico do papel de que está imbuído, como também pelo emprego de estratégias ritualísticas. Estas são de várias espécies, como as sacrificais, em que presenciar a morte desperta fortes emoções que alteram a consciência, as orgiásticas, em que efeito semelhante é obtido pelo exacerbamento sexual e outras de caráter mais introspectivo, .que se valem de procedimentos como orações e meditação em contexto de isolamento pessoal.

Tais rituais muitas vezes envolvem, ainda, canto, dança e, em certas ocasiões, o uso de drogas alucinógenas ${ }^{9}$. Além disso costumam, com freqüência, ter caráter grupal, ou

9 Conforme explica Huxley (1957), não só as drogas, mas a própria dança acompanhada de canto gera alterações orgânicas que induzem experiências de consciência alterada. Isso ocorre porque tal atividade leva à redução da taxa de 
então ser realizados em lugares com valor simbólico, pois a situação coletiva ou ambiental em si já é suficiente para amplificar seus efeitos.

Em termos de medicina, por exemplo, são realizadas cerimônias destinadas a provocar estados de transe em que o xamã, e muitas vezes o próprio paciente, mentalizam imagens de deuses e heróis propícios à cura. Tais cerimônias também podem ser conduzidas em um lugar tido como mágico, ou então em um que seja adornado por objetos com esse significado (como a tenda de um feiticeiro). E xamã e doente podem, ainda, empunhar objetos desse gênero, e com eles fazerem gestos simbólicos.

Em certas situações o xamã, seu paciente, ou ambos, evocam imagens da moléstia a ser curada como sendo um demônio ou animal peçonhento que é combatido e destruído por ambos. Há, inclusive, diversos relatos de materialização de tais animais, que são extraídos do corpo da pessoa, o que representa a retirada de seu mal. Às vezes são induzidas imagens em que o paciente é auxiliado por um deus, herói mitológico ou espírito benigno nesse combate. E outra forma de intervenção utilizada é a de ajudá-lo a formar uma imagem de si mesmo com perfeita saúde, o que também é considerado como fator de cura. Por fim, mais uma estratégia utilizada pelo xamã é a de viajar pelo mundo do além, para resgatar a alma de indivíduos cujos problemas considera decorrentes do fato de ela estar perdida. Neste caso, ele entra num estado em que se percebe em um ambiente sobrenatural, repleto de entidades espirituais, pelo qual transita.

A tradição xamanista, além de ser ainda hoje predominante entre indígenas, também o foi, durante toda a antigüidade, em grandes nações de diversas partes do planeta. Apesar de mais sofisticadas e complexas, as culturas dessas nações mantiveram a crença nas causas espirituais dos acontecimentos vividos pelo homem, e também o emprego de práticas imagéticas semelhantes às dos xamãs.

Em matéria de medicina, um dos exemplos mais remotos desse fato pode ser encontrado entre os assírios e babilônios, que utilizavam os sonhos de seus sacerdotes, além da observação do sol e de outros astros, para fins diagnósticos. E o processo de cura envolvia métodos como a incubação de sonhos do paciente, em que este orava e entoava cânticos antes de dormir, para evocar imagens benéficas em sonhos. Muitas vezes, ainda, ele dormia em templos religiosos, o que intensificava esse processo. Tais intervenções baseavam-se, à semelhança das xamanistas, na crença de que espíritos maus causavam as doenças, sendo necessário apelar-se a divindades para exorcizá-los.

Além desses povos, os egípcios, hindus e gregos antigos tinham crenças e usavam procedimentos médicos similares. Os dos gregos foram os que ficaram mais conhecidos. Acreditavam que manter na mente a imagem de um deus, ou sonhar que ele estava curando eram situações terapêuticas. É também através dos gregos que se tem mais notícias com relação ao processo de incubação de sonhos. Em sua prática, o paciente era levado até a parte mais interna do templo, chamada 'ábaton', para aguardar sonhos de cura, dos quais alguns relatos ilustrativos ainda podem ser encontrados nos dias atuais (e.g. Groesbeck, 1983). Cabe acrescentar no entanto que, como possuíam um conhecimento relativamente evoluído, já valiam-se também de métodos materiais relativamente sofisticados, como a utilização de dietas, banhos e exercícios visando a cura.

Não se deve igualmente esquecer que, paralelamente aos propósitos curativos, as imagens mentais têm sido empregadas, desde a mais remota antigüidade, visando uma diversidade de outros fins. No antigo Egito eram usadas, entre outras coisas, objetivando o controle do clima, na tentativa de prever o futuro e, até mesmo, em encantamentos objetivando a ressurreição dos mortos. E na Assíria, na Babilônia e na Suméria, assim como

oxigênio e ao aumento da de dióxido de carbono no sangue, o que produz modificações no funcionamento do sistema nervoso. 
em outras nações, empregavam-se imagens de fertilidade, na forma de deuses ligados a ela acreditava-se que a presença de tais imagens, materializadas em esculturas, aumentasse a produtividade da terra e a procriação de animais e pessoas.

Já em termos de uma utilização eminentemente religiosa, desprovida de interesses materiais, esta sempre se associou a práticas que levam ao êxtase religioso, um estado alterado de consciência que pode ser atingido através de transe, meditação, sonhos, alucinações e visualizações. Tal estado é considerado como um dos modos fundamentais de se entrar em contato direto com o mundo espiritual, e sua obtenção através do uso de imagens pode ser encontrada, por exemplo, em práticas xamanistas, utilizadas desde a antigüidade até nossos dias.

No extremo oriente, as remotas tradições voltadas para o contato direto com uma realidade transcendente continuaram a ser disseminadas, sem impecilho, desde a antigüidade até nossos dias. Sua influência pode ser claramente percebida em sistemas filosófico-religiosos que se tornaram bastante populares como o budismo, o zen-budismo, a ioga e o tantrismo.

O papel das imagens mentais nesses sistemas é bastante bem ilustrado pelo tantrismo, originado da junção da ioga a idéias do hinduísmo, do budismo e de cultos populares aborígines. A estruturação de suas práticas foi calcada em extenso uso de tais imagens, cuja mentalização é sustentada pela pessoa até que suas forças internas sejam despertadas.

Nesse processo a estratégia utilizada não é a de se abandonar passivamente à contemplação das imagens que surgirem espontaneamente, mas a de produzir deliberadamente as que forem prescritas por um mestre enquanto de posse de perfeita lucidez e auto-controle. O aprendiz deve evocar em seu interior uma progressão de diferentes figuras, que em parte significativa são de mandalas e divindades, e pode ter que treinar muitos anos para que elas se tornem bem vívidas. Acredita-se que só assim conseguirá transcender o mundo das ilusões e perceber a realidade das coisas. E além das de mandalas e de divindades, são ainda utilizadas imagens e sonhos que expressam uma continuidade entre a vida e a morte, como os de batalhas em que o corpo é sacrificado, para se adquirir a noção de que a vida concreta é ilusória.

No ocidente e no oriente próximo, todavia, a situação foi diversa. Muito embora entre indígenas da África e das Américas o xamanismo tenha continuado a encontrar livre curso, o mesmo não ocorreu nas nações de maior avanço tecnológico. Nestas, o uso generalizado de práticas como as que expus acima foi em grande parte bloqueado, a partir da idade média, pela considerável hegemonia de três grandes correntes religiosas: o cristianismo, o islamismo e o judaísmo.

Tais correntes têm em comum o fato de atribuírem basicamente a seus profetas e/ou santos a possibilidade de uma experiência concreta e intensa do divino na vida terrena, excluindo desse tipo de experiência o homem comum. Sendo assim, seus sacerdotes costumam funcionar como intermediários entre os fiéis e o mundo espiritual, e não como facilitadores do contato direto com este último ${ }^{10}$. Tentativas laicas realizadas em tal sentido eram, e às vezes ainda são, encaradas como bruxaria, como contato com demônios e não com

\footnotetext{
10 Uma exceção a isso pode ser encontrada, atualmente, no evangelismo pentecostal. Se bem que não utilize práticas tão diversificadas quanto as de tempos antigos, seus cultos com freqüência são conduzidos de modo a promoverem estados de êxtase religioso, e seus clérigos utilizam muitas vezes procedimentos ritualísticos de cura. Além do mais, não se deve olvidar o fato de que o catolicismo também sempre foi rico em imagens e rituais que podem, em alguma medida, favorecer uma vivência mais intensa do religioso. Não obstante, tal vivência costuma ser algo relativamente sutil, bem menos palpável que a do êxtase religioso. E atitudes como a adotada até há pouco tempo de rezar as missas em latim, uma língua bastante distante da vida concreta dos fiéis, ostensivamente inibem o tipo de experiência em questão.
} 
espíritos benéficos. E eram, por isso, até poucos séculos atrás, punidas com a morte, o que revela a grande repressão imposta às práticas aqui consideradas.

Apesar disso, de maneira relativamente clandestina, elas foram preservadas. Isso ocorreu tanto através de esforços isolados, em que um seu conhecedor as transmitia para um ou alguns aprendizes, quanto de movimentos mais organizados, caso das seitas esotéricas. Estas últimas inspiraram-se, por um lado, em antigas tradições consideradas pagãs, como as druídicas da cultura celta, e as das antigas religiões do oriente, da Grécia e de Roma. Por outro, contudo, também basearam-se em preceitos das próprias grandes religiões.

Foi assim que, já nos primeiros séculos da nossa era, surgiu o gnosticismo cristão, em que se continuava a praticar exercícios espirituais imagéticos, como a mentalização de séries de imagens sagradas, sendo a última a de Cristo. E coerentes a tal gnosticismo desenvolveram-se uma multiplicidade de seitas que existem até os dias atuais, caso da rosa-cruz, do kardecismo, da teosofia, da ciência cristã e da antroposofia. Da mesma forma, vinculada ao judaísmo estruturou-se a cabala, tradição milenar que ainda hoje tem seus adeptos e que também se vale de imagens mentais: exemplo disso é a busca que empreende de elevação da alma humana até Deus, o que pode ser feito imaginando-se uma viagem com várias etapas em que se vencem obstáculos e anjos hostis.

Além do mais, na Renascença houve um importante personagem não vinculado de maneira notória a seitas como as que mencionei acima, mas cujas atividades também estiveram associadas ao uso das imagens mentais. Esse personagem foi Paracelso, o famoso médico e alquimista suíço que viveu no século XVI. Ao mesmo tempo em que seu trabalho inovador levou-o a ser considerado o pai das modernas farmacologia e medicina científicas, ele manteve a crença de que fatores espirituais e a imaginação estavam associados à doença e à cura.

Algumas de suas concepções eram semelhantes às dos povos antigos, como a de que as doenças poderiam ser geradas pela influência de demônios e bruxas e sua cura obtida através do poder de Deus. Não obstante, acreditava igualmente que a imaginação do indivíduo podia adoecê-lo ou curá-lo. Via, desse modo, particular importância em lidar com os processos imaginários, os quais não se resumem em imagens mentais mas, não obstante, são em grande medida constituídos por elas. A relevância que tais processos assumiam em seu pensamento fica bastante evidente na seguinte frase de sua autoria: "O espírito é o mestre, a imaginação a ferramenta e o corpo o material moldável..." (Samuels \& Samuels, 1975, p. 216). Ademais, entre as práticas por ele recomendadas figurava a utilização de sonhos do terapeuta para fins diagnósticos.

Após Paracelso a medicina embasada num método de teor mais científico foi progressivamente ganhando força, dominando o panorama ocidental. Apesar disso, houve os que mantiveram uma orientação espiritualista, continuando a fazer amplo uso das imagens mentais em suas estratégias curativas. Dentre estes posso mencionar os rosacruzes, kardecistas e cientistas cristãos, que além de interesses espirituais também lidam com problemas de saúde.

Dois tipos de intervenção muito usados pelos rosacruzes são imaginar-se fazendo uma viagem até o sol, o que acreditam que aumente a energia da pessoa e facilite sua cura, e visualizar luz branca circundando o corpo ou especificamente a região afetada do mesmo. Imagens como estas são evocadas não só pelo próprio doente, como por outras pessoas que estejam interessadas em sua cura.

Este último gênero de mentalização de imagens, feita por um grupo de indivíduos para favorecer a resolução de problemas de outro é, da mesma forma, um dos métodos básicos do kardecismo. Já no referente aos cientistas cristãos, um procedimento fundamental de cura consiste em a pessoa visualizar-se saudável, à semelhança do que se faz há vários milênios em certas correntes xamanistas. 
Enfocando, por fim, mais especificamente o cenário atual, um primeiro fato digno de nota é o de que, a partir do início do século XX, houve o reconhecimento relativamente generalizado de que fatores psíquicos são importantes tanto no surgimento de problemas físicos como em seu restabelecimento. Diversos estudos, que comprovaram fenômenos como a somatização de distúrbios emocionais e o efeito placebo (cf. Samuels \& Samuels, 1975), reabriram o caminho para a exploração de métodos psicológicos para lidar com problemas orgânicos, desta feita desvinculados do espiritualismo.

E as imagens mentais, haja vista seu alto poder de mobilização tanto emocional como fisiológica, desempenham papel central em muitos desses métodos. Especula-se, inclusive, que estejam envolvidas no efeito placebo (cf. Samuels \& Samuels, 1975). É possível que a crença num pretenso medicamento gere uma expectativa de recuperação que induza a pessoa, consciente ou inconscientemente, a formar imagens de si mesma curada, do mesmo modo que deliberadamente se faz há muito em alguns tratamentos espirituais, conforme já mencionei.

Em virtude do que expus acima, surgiram vários tipos de intervenção curativa de teor imagético não vinculados ao espiritualismo, paralelamente ao prosseguimento das práticas espirituais do mesmo gênero (caso, por exemplo, das adotadas por formas remanescentes do xamanismo e do cristianismo esotérico).

Um desses tipos de intervenção, grandemente difundido e pesquisado, é o treinamento autógeno de J. H. Schultz, criado há já várias décadas. Trata-se de um trabalho que articula relaxamento à mentalização de uma série de imagens de cores, objetos, conceitos e sentimentos, para facilitar processos fisiológicos auto-reguladores. É bastante utilizado, em associação com estratégias médicas tradicionais, para o tratamento de diversos problemas como os de coluna, cardíacos, ginecológicos, gástricos, etc...

E mais um emprego médico de imagens que tem sido explorado com grande sucesso nos últimos anos relaciona-se ao combate ao câncer. Tal emprego consiste, em certas situações, no uso de gravuras de tumores em remissão e dos próprios raios $\mathrm{X}$ do paciente para orientar as imagens por ele formadas, que devem ocorrer no sentido da regressão do mal. Esse procedimento é associado, em regra, a um trabalho psicoterapêutico que visa transformar atitudes negativas frente à doença, a si mesmo e à vida de maneira geral em positivas, pois acredita-se que uma postura razoavelmente otimista é fundamental para a superação da doença (Samuels \& Samuels, 1975).

Além disso, as imagens mentais têm apresentado, ainda, utilidade em situações de parto e anestesia (principalmente associadas à hipnose), bem como em oftalmologia, na forma de exercícios oculares imaginários (Samuels \& Samuels, 1975). Há, também, relatos de sua utilização bem sucedida com problemas como estomatite (Andrews \& Hall, 1990) e dor nas costas (Rancour, 1991), sendo ainda sugerida sua aplicação a uma vasta série de outras perturbações orgânicas, como é possível constatar em Epstein (1990). Este último autor descreve vários exercícios simples, autoministráveis, para lidar com problemas circulatórios, dermatológicos, digestivos, endócrino-metabólicos, geniturinários, etc.. E embora seus exercícios, se realizados isoladamente, pareçam-me demasiado simples para surtirem um efeito intenso no combate a distúrbios mais sérios, creio que possam ser, em certos casos, proveitosos quando conjugados a outras estratégias, tanto imagéticas como psicoterápicas, fisioterápicas ou médicas.

O uso atual das imagens mentais não se restringe, entretanto, à terapêutica médica, que acabei de mencionar, nem à psicológica, que abordarei mais à frente. Há ainda outras áreas em que tais imagens começaram a ser empregadas. Uma delas é a dos esportes (cf. Kendall, Hrycaiko, Martin, \& Kendall, 1990; Savoy, 1993; Suinn, 1983). Segundo levantamento feito por Suinn, estratégias imagéticas vêm sendo adotadas e pesquisadas para o 
aperfeiçoamento em práticas esportivas bastante variadas como basquetebol, tênis, esqui na neve, futebol americano, corrida, golfe, mergulho, ginástica, arco e flecha, luta corporal e boliche ${ }^{11}$. Este autor divide a grande maioria desses trabalhos em dois grupos: um norteado pelo propósito de incrementar reações adequadas, e outro pelo de eliminar reações inadequadas.

Uma aplicação típica de imagens no desportismo é o 'ensaio imagético'. Nele, a pessoa é levada a imaginar-se o mais minuciosa e concretamente possível realizando a atividade que deseja aperfeiçoar. Tal exercício geralmente se inicia por uma sessão de relaxamento, o que parece propiciar a evocação de imagens mais vivazes e detalhadas. E pode ser utilizado tendo em vista qualquer dos dois propósitos que citei no parágrafo anterior: o indivíduo pode tanto imaginar-se repetindo comportamentos bem sucedidos que já conhece, para aprimorá-los e aumentar sua freqüência, como corrigindo erros ou exercitando estratégias cognitivas para combater emoções e atitudes inadequadas (Suinn, 1983).

Outra área em que as imagens mentais têm sido utilizadas é a do aperfeiçoamento da capacidade de memorização (e.g. Bagley, 1987, McDaniel \& Pressley, 1987). Tal uso pode ser justificado pela pelo fato de que é mais fácil recordar imagens e palavras concretas que palavras abstratas, conforme pode ser visto em Paivio (1971, 1986). A teoria deste autor a respeito do assunto baseia-se na existência de dois códigos para armazenar informações na memória: o verbal e o pictórico. Segundo essa teoria as imagens, assim como as palavras concretas, são estocadas redundantemente nesses dois códigos, e por isso melhor rememoradas que as palavras abstratas, que só podem ser armazenadas no código verbal.

Independente de a teoria de Paivio $(1971,1986)$ ser ou não a mais adequada a respeito do funcionamento da memória, é fato comprovado que as coisas são mais facilmente recordadas quando associadas a imagens, tanto exteriores como mentais. Tal permite que estas últimas assumam papel relevante não só em métodos mnemônicos voltados para o aperfeiçoamento de habilidades cognitivas das pessoas, como também em outros domínios. Alesandrini e Sheikh (1983), por exemplo, defendem o uso de métodos para eliciar imagens mentais em estratégias de publicidade, como forma de aumentar as chances de que o consumidor se lembre dos produtos e serviços divulgados pelas propagandas.

E mais um campo em que as imagens mentais começaram recentemente a ser utilizadas é o da informática. Em seu famoso livro "Eu, Robô", Isaac Asimov (1950/1970) vislumbrou uma possibilidade insólita: a de um robô portador de um cérebro eletrônico sofisticado possuir habilidades telepáticas. Quando li esta estória, não pude atinar com o motivo pelo qual o autor haveria vislumbrado uma situação tão surpreendente. Nunca me ocorreria atribuir uma tal capacidade a um artefato eletrônico. Não obstante, apenas algumas décadas após a publicação do livro em questão, tal possibilidade começa a se concretizar: já estão sendo produzidos aparatos que permitem operar programas de computador através de ondas

cerebrais.

E uma das maneiras básicas de, com essa finalidade, se aprender a controlar estas ondas é a mentalização de imagens (Browne, 1995).

Atualmente é ainda necessário conectar o sistema de hardware ao indivíduo por fios com elétrodos que são fixados em seu couro cabeludo, o que não caracteriza muito propriamente um processo telepático. Contudo, a tecnologia eletrônica avança de modo excepcionalmente veloz em nossos tempos. Sendo assim, é bastante plausível supor que, em poucos anos, será possível fabricar amplificadores de ondas cerebrais tão sensíveis que

11 Essas estratégias, e as que mencionarei à frente, referem-se especificamente ao uso de imagens mentais, e não a tudo que se costuma chamar na área desportiva de 'prática mental', ou 'ensaio mental'. Esta última, mais genérica, abarca qualquer forma de exercício encoberto relacionado a determinada atividade física. E isso inclui não só imagens ligadas a tal atividade, mas também o simples pensar a respeito dela (cf. Suinn, 1983). 
permitam captação à distância, sem nenhum meio material como intermediário. $\mathrm{E}$ isto certamente poderá ser considerado como telepatia.

Para encerrar, uma última aplicação de imagens em informática que pode ser citada é a proposta por Eisenstadt, Price e Domingue (1992). Esses autores descrevem um conjunto de técnicas de visualização elaboradas para permitir que iniciantes adquiram intimidade com a execução de programas, e que especialistas observem abstrações de alto nível dos mesmos que facilitem a resolução de problemas.

\section{O uso de imagens mentais no âmbito da psicoterapia}

Tomando agora mais estritamente o campo da psicoterapia, nele um dos principais valores das imagens mentais reside em serem recurso eficiente para o acesso a aspectos profundos do mundo interior, bem como para o incentivo da criatividade no enfrentamento de problemas. Além disso, como já disse, seu emprego está muitas vezes associado a grande envolvimento emocional e, mesmo, fisiológico. Devido a isso podem despertar fortes sensações e afetos, intensificar sensações e sentimentos tênues, ou ainda provocar alterações orgânicas, às vezes bastante acentuadas. Sendo assim, tais imagens consistem em importantes geradores de mudanças cognitivas, emocionais, comportamentais e psicossomáticas, alvos básicos da terapêutica psicológica.

Também deve-se levar em conta que as imagens mentais, como coloca Lusebrink (1990) "parecem estar mais intimamente ligadas à experiência do indivíduo que os rótulos verbais que dão nomes a essa experiência" (p. 27). Isso tendo em vista que "quando os eventos são codificados na forma de linguagem (seja verbal ou matemática), eles tornam-se abstratos e perdem seu impacto direto sobre nossa experiência" (Singer \& Pope 1978, p. 9) ${ }^{\mathbf{1 2}}$. Por esse motivo tais imagens apresentam particular relevância para as abordagens psicoterápicas experienciais, em cujo trabalho é considerado prioritário que o indivíduo mantenha-se o mais próximo possível da concretude de suas vivências.

Considero igualmente importante ressaltar que autores como Sheikh e Jordan (1983) apontam para o fato de as imagens ainda permitirem a expressão de uma gama mais ampla de conteúdos que a possibilitada pela linguagem verbal ${ }^{13}$. A seu ver esta última, devido à sua limitação nesse sentido, sutilmente impede que certos fenômenos subjetivos sejam expressos e, inclusive, que se tenha consciência deles.

Outro ponto a favor das imagens está em que, não obstante o método mais tradicional de se lidar terapeuticamente com as mesmas seja analisar seu conteúdo, elas muitas vezes têm um efeito terapêutico direto, ou seja, apenas o fato de vivenciá-las pode trazer benefícios para a pessoa (cf. Reed, 1985; Sheikh \& Jordan, 1983). E isso tem sido explorado proveitosamente em certas estratégias de trabalho, como mostrarei adiante.

Finalmente, acho ainda necessário salientar que elas podem facilitar o trabalho com pessoas cuja formação intelectual é pouco sofisticada. Isso por serem mais palpáveis que os simbolismos e conceitos abstratos com que lidam as orientações psicoterapêuticas predominantemente verbais e que essas pessoas têm dificuldade de entender (cf. Sheikh \& Jordan, 1983).

12 Estes autores estão provavelmente se referindo à linguagem de teor racional, uma vez que a linguagem poética freqüentemente gera grande envolvimento emocional e, mesmo, visceral.

13 Novamente linguagem verbal de teor racional, já que a poética permite a expressão de uma amplitude muito grande de significados. Não se deve esquecer também que as próprias imagens mentais usadas em psicoterapia são, muitas vezes, descritas verbalmente por quem as evocou. E isso não impede que, através dessa descrição, que é uma forma mais figurativa de se referir a fenômenos internos, a pessoa tenha a possibilidade de expressá-los com maior acuracidade que se procurasse falar diretamente sobre eles. 
Sendo assim, consistem em instrumento de grande potencial na atuação junto a populações carentes, que não têm acesso a uma boa formação educacional. Isso reveste-se de particular importância uma vez que as escolas psicoterápicas tradicionais apresentam-se, em regra, pouco eficientes com essas populações. Tal ocorre exatamente porque tais escolas trabalham, quase sempre, de maneira discursiva (Arcaro, 1991; Arcaro \& Mejias, 1990). E conforme pude constatar em meus vários anos de atendimento a pessoas dos estratos sócioeconômicos mais baixos, muitas vezes estas sequer possuíam vocabulário para descrever várias emoções e estados subjetivos que, para mim, pareciam elementares (como ciúme, inquietude, euforia, e outros) ${ }^{14}$.

É por motivos como os que acabei de colocar que, desde os primórdios da psicoterapia, inúmeras de suas abordagens vem utilizando imagens mentais de maneira sistemática. O primeiro emprego de tais imagens já pode ser encontrado nos passos iniciais do desenvolvimento da psicanálise: Breuer e Freud, através da hipnose, procuravam evocar imagens de eventos traumáticos em pacientes que apresentavam distúrbios neuróticos. Acreditavam que tais distúrbios estivessem associados às situações reveladas por essas imagens, e que a catarse ocasionada pela evocação das mesmas podia-se constituir em importante fator de cura. Ademais, julgavam que a conscientização a respeito de tais situações consistisse num enriquecimento relevante da personalidade (Samuels \& Samuels, 1975). Posteriormente Freud substituiu seu uso da hipnose por uma técnica imagética que não exigia a indução de um estado de transe. Tal técnica consistia apenas em pressionar levemente a cabeça da pessoa, sugerindo-lhe que observasse as imagens que apareciam quando a pressão era aliviada (Sheikh \& Jordan, 1983).

Mais tarde, Freud abandonou também esse último procedimento em favor da associação livre, já que passou a acreditar que tais imagens eram fenômenos defensivos e regressivos (Sheikh \& Jordan, 1983; Witmer \& Young, 1985). Afastou-se, assim, da utilização de métodos para evocar imagens mentais de modo deliberado. Não obstante, continuou a dar relevo à interpretação dos sonhos, os quais considerava a via regia de acesso ao inconsciente (e.g. Freud, 1900/1972), no que tem sido acompanhado por inúmeros seguidores até os dias de hoje. A isso se acresce o fato de a psicanálise utilizar igualmente imagens espontâneas que surgem em fantasias e devaneios do paciente para explorar sua problemática conflitual.

Além do mais foram elaboradas, dentro da orientação psicanalítica, diferentes abordagens e estratégias psicoterápicas predominantemente voltadas para a utilização de imagens mentais. Dentre as abordagens figuram a 'psicoterapia reveladora emergente ${ }^{15}$ de Reyher (1978), que usa associação livre de imagens, e a 'terapia de psico-imaginação ${ }^{16}$ ' de Shorr (1978), baseada na psicanálise interpessoal de H. S. Sullivan. E quanto às estratégias, é possível mencionar o uso de imagens intuitivas do terapeuta (Trinca, 1985, 1987, 1988), o de imagens do desenvolvimento humano propostas pelo analista a seu paciente (Chuah, 1985), o de técnicas imagéticas voltadas para o incentivo da criatividade (Mattes \& Robbins, 1981), ou então associadas ao trabalho com sonhos (Schaub \& Schaub, 1990), e o de imagens de implosão como auxiliares na tarefa de elaborar conteúdos emergentes (Silverman, 1987).

Deixando a psicanálise tem-se que mais uma escola cujas origens igualmente remontam ao início da história da clínica psicoterápica, e que faz amplo uso das imagens mentais, é a psicologia analítica de C. G. Jung (e.g. Jung, 1964; Jung, 1934/1987; Jung, 1961/1989; Stein, 1993). Tal escola está singularmente voltada para a exploração de

\footnotetext{
14 Diga-se de passagem, foi impulsionado por esse gênero de dificuldade, que enfrentei no trabalho com essas pessoas, que dei meus primeiros passos mais consistentes no uso de estratégias imagéticas.

15 Emergent uncovering psychotherapy na língua original.

16 Psyco-imagination therapy na língua original.
} 
conteúdos oníricos, de modo a ter acesso aos processos inconscientes das pessoas. Jung inclusive acreditava que os sonhos exerciam influência direta no equilíbrio psíquico, assumindo um papel de compensar a atitude psicológica do estado de vigília (e.g. Jung, 1934/1987). Por outro lado, também desenvolveu um procedimento de fantasia dirigida, ao qual chamou 'imaginação ativa', em que o indivíduo não se restringe a acompanhar o desenrolar de suas imagens interiores, mas participa desse desenrolar de modo atuante, interferindo nos fatos e inquirindo os personagens que nele tomam parte (cf. Hall, 1986; Sanford, 1987).

E ainda associados a essa escola podem ser encontrados métodos relativamente recentes de trabalhos com sonhos, diferenciados do estilo clássico de interpretação adotado por Jung. Um dos autores mais criativos a esse respeito é Reed (1985). Esse autor, por exemplo, adaptou a antiga prática de incubação de sonhos, empregada por diferentes sociedades do mundo antigo, para utilização atual. Um segundo método por ele elaborado é a 'incubação grupal de sonhos', que se diferencia significativamente da incubação individual. Tal método compreende práticas grupais, que induzem um conjunto de pessoas a sonharem com assuntos referentes a uma outra que, por sua vez, participa desse conjunto apenas como alvo dos sonhos dos demais.

Reed (1985) desenvolveu igualmente uma série de procedimentos objetivando facilitar a recordação das imagens oníricas em estado de vigília, haja vista que muitas pessoas apresentam dificuldade em fazê-lo de maneira freqüente ${ }^{17}$. Da mesma forma, elaborou estratégias para a utilização dos sonhos visando o aumento da criatividade, que é mais uma área em que o papel destes pode ser relevante. Por fim, cabe mencionar que tal autor defende, inclusive, que os sonhos são tão capazes de levar a mudanças pessoais como qualquer experiência objetiva. Sendo assim, julga que muitas vezes não é necessário interpretá-los, pois apenas vivenciá-los já constitui um episódio de crescimento psicológico.

Tendo encerrado minha breve exposição sobre a abordagem junguiana, julgo igualmente necessário voltar-me para o uso de imagens em mais uma importante linha de pensamento da psicologia: o comportamentalismo. Do mesmo modo que as escolas acima, ele emprega inúmeras técnicas imagéticas em aplicações clínicas. Em seu caso, entretanto, essas técnicas costumam ater-se ao uso de imagens de vigília, sugeridas pelo terapeuta, para provocar diretamente mudanças nas pessoas. Não buscam, portanto, levantar material inconsciente para ser analisado, como acontece na grande maioria das estratégias psicoterápicas supracitadas.

Um dos métodos imagéticos mais clássicos da psicologia comportamental é seguramente a dessensibilização sistemática. Ele associa relaxamento a uma seqüência de imagens progressivamente mais ansiógenas, visando o tratamento de fobias (e.g. Wolpe, 1978). Um segundo desses métodos, igualmente voltado para a superação de fobias, é a terapia implosiva (e.g. Levis, 1993; Stamplf \& Levis, 1967). Nele o terapeuta induz o paciente a formar imagens das cenas que lhe provocam maior ansiedade pois, se tais imagens forem mantidas em mente por certo tempo, muitas vezes o potencial ansiógeno das situações que representam se esvai.

E também é possível citar o condicionamento encoberto (e.g. Cautela \& McCullough, 1978), que se vale de imagens relacionadas a circunstâncias comportamentais como punição, reforçamento positivo, reforçamento negativo e extinção para alterar o comportamento das pessoas. Finalmente, para encerrar os exemplos de utilização de imagens mentais na terapia comportamental, ainda posso mencionar a modelação encoberta. Tal procedimento consiste em o indivíduo formar imagens de um modelo desempenhando um

17 Tenha-se em mente que tal recordação é importante para uma estratégia terapêutica que, como a junguiana, dê grande relevo ao trabalho com o tipo de material em questão. 
comportamento que ele, indivíduo, deseja adquirir, para efetivamente desenvolver tal comportamento (Kazdin, 1978).

Além da psicanálise, da psicologia analítica de Jung e do comportamentalismo, mais um grande ramo da psicologia que faz uso bastante freqüente de imagens mentais é o humanismo. Essa vertente de estudo e atuação é, aliás, a principal responsável pela ampla difusão de estratégias imagéticas ocorrida na atualidade. Isso se deve, em grande medida, ao fato de a maior parte das abordagens que a compõem serem experienciais. Estas, como já mencionei, dão muita ênfase à experiência concreta, considerando discussões verbais menos relevantes. E as imagens mentais não só parecem, como já disse, estar bastante próximas de tal experiência direta, como podem ser utilizadas com bastante facilidade no trabalho terapêutico.

A abordagem humanista que apresenta maior proeminência no emprego e na disseminação de métodos imagéticos é a gestalt-terapia (cf. Sheikh \& Jordan, 1983). Nela, o uso de imagens está muitas vezes associado à dramatização, individual ou grupal, dos elementos e personagens que as compõem. Isso pode ser visto, entre outros, no método de lidar com sonhos desenvolvido por Perls (e.g. Perls, 1976, 1985) e complementado, para trabalho com grupos, por Zinker (1977). No plano individual, o cliente é levado a interpretar o papel não só de pessoas que compõem suas imagens oníricas, como também de objetos e partes dos cenários que tais imagens compreendem. Já no grupal, após o sonho ser trabalhado com o próprio sonhador, da maneira que acabei de descrever, ocorre uma encenação coletiva do mesmo gênero.

Mais um procedimento da gestalt que também envolve dramatização associada a imaginação ${ }^{18}$ é a chamada 'cadeira vazia'. Consiste em o cliente ser orientado a imaginar e atuar um diálogo entre ele e uma pessoa com quem tenha assuntos para resolver, ou entre duas polaridades de um conflito interno que esteja vivendo. A encenação, neste caso, é feita com o auxílio de duas cadeiras, ou quaisquer tipos de assento: quando se senta no primeiro deles, o indivíduo faz o papel de si próprio e, quando no segundo, o da pessoa com quem pretensamente está dialogando (cf. Zinker, 1977).

Cabe acrescentar que, afora o emprego de dramatização, a gestalt utiliza outros tipos de trabalho com imagens. Faz, por exemplo, amplo uso de fantasia dirigida (e.g. Stevens, 1977), sendo inclusive uma das maiores responsáveis pela grande divulgação atual de tal recurso imagético na psicologia. Prova disso é que, ao menos neste país, muitos profissionais chamam o referido recurso não de fantasia dirigida, mas sim de 'exercício de gestalt'. Proceder dessa forma é, evidentemente, incorreto, já que existem, e sempre existiram, muitos outros tipos de atuação, dentro e fora da psicologia, que se valem da estratégia em questão. O fato, no entanto, evidencia claramente que muitos profissionais, na atualidade, tiveram notícia dela através da abordagem ora considerada.

Passarei agora para outro grande movimento da psicologia dos dias de hoje, a corrente transpessoal, que surgiu como um desdobramento do humanismo (cf. Boainain Jr., 1995; Smith, 1990). À semelhança deste, também ela é composta por abordagens de estilos diversos que, no entanto, apresentam algumas características básicas comuns. Entre essas características, uma de grande relevo é o interesse por estados alterados de consciência. Tal interesse está voltado, principalmente, para os estados em que a consciência se torna mais

18 Tenha o leitor em vista que não estarei falando estritamente de imagens mentais quando me referir a imaginação, uma vez esta não é composta só por imagens, mas também por outros fenômenos psíquicos. Como já expliquei, mesmo processos eminentemente imagéticos, como a fantasia dirigida e os sonhos, não são, no mais das vezes, constituídos exclusivamente por imagens mentais, embora nesses casos elas geralmente sejam o elemento predominante. Entretanto, sequer esse predomínio ocorre com tanta freqüência no que se refere à imaginação. Muitos processos imaginários podem ser mais calcados no pensamento abstrato que em imagens mentais. De qualquer maneira, tais imagens costumam, em alguma medida, estar presentes nesses processos. Sendo assim considero, à semelhança de autores como Sheikh e Jordan (1983), que quaisquer trabalhos ligados à imaginação também consistam, ao menos parcialmente, em práticas imagéticas. 
ampla que o habitual, atingindo níveis que supostamente transcendem o indivíduo, ou seja, níveis transpessoais. E outra característica importante da referida corrente, que também analisarei melhor mais adiante, é adotar a idéia de processos supraconscientes, os quais envolvem potenciais psicológicos superiores aos que as pessoas normalmente apresentam (cf. Boainain Jr., 1995).

Em função disso, um dos maiores valores das imagens para essa vertente da psicologia reside em elas consistirem num instrumento produtivo para o acesso a estados ampliados de consciência e a potenciais psíquicos superiores aos usuais. Ilustração de tal fato pode ser encontrada em Foote (1988), que descreve uma técnica de fantasia dirigida que objetiva a visualização de material imagético associado aos chacras da ioga, bem como a processos supraconscientes (estes últimos articulados em imagens que simbolizam o que o autor chama de 'eu superior'). E ainda pode ser mencionado o 'método de imagens em movimento' de Schneider (1989), um procedimento que envolve quatro passos e sintetiza várias técnicas de exploração da consciência.

Além dos exemplos que acabei de citar, a corrente transpessoal se vale igualmente de outros métodos de mentalização de imagens, muitas das quais simbólicas. Tais métodos, inclusive, algumas vezes são associados ao emprego de meditação. Do mesmo modo, o referido ramo da psicologia compreende vários tipos de trabalhos com sonhos, alguns dos quais inspirados pela psicologia analítica de Jung e pela gestalt-terapia (Tabone, 1988).

Também no que tange ao movimento da psicologia presentemente discutido, merece especial referência a psicossíntese. Essa escola, fundada pelo psiquiatra italiano Roberto Assagioli, ao mesmo tempo é peça importante de tal movimento nos dias atuais e uma de suas principais precursoras, haja vista sua antigüidade. Exerceu, por conseguinte, influência significativa sobre práticas e concepções transpessoais mais recentes. Entre seus aspectos característicos estão a ênfase na necessidade de desenvolvimento espiritual, a crença numa instância supraconsciente e também um estilo eclético e holístico, que integra métodos de diversas abordagens psicológicas ocidentais a técnicas meditativas orientais. Quanto às estratégias imagéticas por ela adotadas, pode-se citar a visualização de símbolos, diversas formas de fantasia dirigida, inclusive a imaginação ativa de Jung, e o uso de imagens expontâneas (cf. Assagioli, 1965; Hardy 1989; Sheikh \& Jordan, 1983; Tabone, 1988).

A par do que já expus acima sobre o humanismo e a psicologia transpessoal, mais uma ilustração freqüentemente encontrada do emprego de imagens, em ambas essas vertentes, é a estratégia de evocar a imagem de um conselheiro interior. Um dos diversos modos pelo qual isso pode ser feito é a já mencionada técnica de Foote (1988). Em termos genéricos, o intuito fundamental dessa estratégia é auxiliar o indivíduo a entrar em contanto com fontes inconscientes de conhecimento, bem como a familiarizar-se com outros aspectos de si mesmo até então excluídos de sua consciência (cf. Chapin, 1989; Sheikh \& Jordan, 1983).

E ainda associado ao eixo humanista-transpessoal, mais um tipo de compreensão dentro da qual as imagens mentais podem apresentar importante papel é a referente a 'mitologia pessoal'. Esta visão supõe que a maneira pela qual compreendemos e organizamos nossas existências é norteada por 'mitos pessoais'. Tais mitos desempenham, para cada um, as funções explicativas e orientadoras que os mitos culturais apresentam em âmbito social. São crenças profundas, em regra inconscientes, que vão se desenvolvendo, com o correr da vida, por influência de fatores sócio-culturais, familiares e individuais. E é através dessas crenças que interpretamos nossas experiências e estruturamos nossa conduta (Ciornai, 1995; Feinstein \& Krippner, 1997; Krippner, 1987).

Devo esclarecer que, neste caso, o uso de imagens não se dá necessariamente através de procedimentos específicos, peculiares à estrutura de compreensão que acabei de 
descrever. Antes pelo contrário, tal estrutura consiste, em maior medida, numa contribuição para o entendimento do material imagético obtido de diversas formas no trabalho terapêutico, contribuição esta que pode apresentar relevância tanto teórica quanto prática (Krippner, 1987).

Uma vez terminada a exposição sobre os movimentos humanista e transpessoal, pode-se considerar mais uma grande e tradicional linha de atuação psicoterápica que, em alguns momentos, faz uso das imagens mentais, ou seja, o psicodrama. Em tal uso, à semelhança do já exposto relativamente à gestalt-terapia, trabalha-se o material imagético através de dramatização. Uma das formas pelas quais isso pode ser feito, tanto em terapia individual como grupal, é o 'psicodrama do sonho' ou 'onirodrama', em que o sonho é encenado na situação terapêutica (e. g. Schutzenberger \& Weil, 1977; Wolff, 1981).

Além disso, Schutzenberger e Weil (1977) também sugerem mais uma estratégia que guarda fortes semelhanças com outra das já descritas em associação à gestaltterapia: a 'cadeira vazia do terapeuta'. Em tal estratégia, usada em psicodrama de grupo, coloca-se um assento vazio no centro do grupo, para que seus participantes expressem seus sentimentos como se o terapeuta estivesse lá sentado, mas ao mesmo tempo imaginando que ele não está presente na sala. $\mathrm{E}$ os mesmos autores ainda descrevem outra estratégia que associa imaginação a recursos dramáticos, à qual chamam de 'psicodrama de projeção no futuro'. Neste caso trata-se, conforme sugere o nome, de uma dramatização de eventos que se supõe irão acontecer futuramente.

Por fim, ainda no âmbito das grandes escolas e movimentos da psicoterapia, outro ramo cada vez mais popular desse gênero de atividade, e que está associado ao emprego de imagens, é o ligado à utilização de recursos artísticos (cf. Andrade,1993; Carvalho, 1995). Tal utilização se dá através de diversas abordagens terapêuticas, baseadas em diferentes fundamentações teóricas, e se constitui em forma importante de representar imagens mentais. Conforme expõe Lusebrink (1990), há diversos modos de explicitar e elaborar tais imagens, além de descrevê-las e discuti-las verbalmente. E a expressão artística possibilita caracterizálas usando-se sua própria modalidade estrutural como veículo. Há, por exemplo, meios visuais, como desenho, pintura e escultura, auditivos, como canto e música instrumental, e cinestésicos, como dança e outros movimentos corporais, para a expressão de imagens dessas diferentes modalidades. Isso permite comunicar com maior precisão certos aspectos das imagens que são difíceis de se explicitar através da linguagem verbal, o que pode ser, em alguns casos, um enriquecimento importante na exploração de material imagético.

Ademais, um dos maiores méritos do emprego de recursos artísticos em psicoterapia não está, a meu ver, propriamente em seu potencial de retratar as imagens mentais. Está, sim, no de evocar imagens desse teor com conteúdos significativos, à semelhança de outras práticas já descritas. A pessoa que faz, por exemplo, uma pintura numa sessão de arte-terapia, não a faz, muitas vezes, para representar uma imagem mental da qual tenha consciência prévia. Freqüentemente principia por agir de maneira relativamente intuitiva, orientada por um sentimento nebuloso, indistinto. No decorrer do trabalho, contudo, vão lhe ocorrendo cada vez mais claramente as imagens que deseja pintar, as quais, portanto, são evocadas pela atividade que está realizando.

Encerrada minha explanação sobre o uso de imagens nos movimentos e escolas da psicoterapia mais amplamente difundidos, resta falar de algumas abordagens independentes menos conhecidas. Tais abordagens fazem, igualmente, aplicação sistemática de técnicas imagéticas e, em alguns casos, chegam mesmo a basearem fundamentalmente sua metodologia de atuação em tais técnicas.

Na Europa há exemplos já bastante antigos dessas linhas de trabalho. De acordo com Sheikh e Jordan (1983), já no final do século XIX Pierre Janet (1898) utilizava 
intervenções imagéticas de teor psicoterapêutico. Sua estratégia era a de substituir uma imagem mental por outra para auxiliar pacientes histéricos a superarem o que chamava de 'idéias fixas'. Também Alfred Binet (1922), embora mais conhecido por seu trabalho em psicometria, desenvolveu um procedimento terapêutico denominado 'método dialógico'. Neste, o paciente conversava com imagens visuais quando num estado a que tal estudioso se referia como 'introspecção provocada'. E a primeira abordagem psicoterápica amplamente baseada em exercícios imagéticos foi a de Carl Happich (1932). Esse autor expandiu o trabalho de Binet, induzindo o que denominava de 'imagens emergentes' com o emprego de relaxamento, técnicas respiratórias e meditação.

$\ddot{E}$ importante acrescentar ainda que, conquanto Freud, na virada do século, houvesse abandonado a exploração de imagens não oníricas, alguns psicanalistas continuaram a tirar proveito delas. Ficando apenas nos mencionados por Sheikh e Jordan (1983), tem-se em primeiro lugar Silberer que, no começo deste século, percebeu a natureza simbólica de imagens hipnagógicas e seu valor para a investigação de processos inconscientes. Além dele, Pierce Clark (1925) se valia de imagens visuais, que chamava de 'fantasmas', visando o acesso a memórias da infância. Foi provavelmente ele o primeiro a utilizar o método de associação livre de imagens, recuperado por Reyher (e.g. Reyher 1978) em época mais recente. E mesmo a própria filha de Freud, Anna, usou imagens tanto espontâneas como dirigidas no trabalho com crianças.

Pode-se citar também, ainda numa vertente européia, abordagens mais atuais que se baseiam fundamentalmente em métodos imagéticos. Uma delas é a de Desoille (1961, 1965), que chamou sua técnica de 'sonho acordado dirigido'. E outra é a de Leuner (e.g. Leuner, 1978; Winkler, 1987), denominada 'imagens afetivas guiadas'. Ambas estas abordagens usam, basicamente, imagens simbólicas e fantasia dirigida para pesquisar conflitos, auto-imagem, memórias infantis e outras questões associadas a distúrbios psicológicos. E sua estratégia para elaborar o material imagético obtido do cliente é geralmente interpretativa, baseada numa visão psicodinâmica.

Tomando agora os Estados Unidos, tem-se que o predomínio de um comportamentalismo mais radical bloqueou em grande medida, até fins da década de '50, o estudo sobre experiênciais interiores, o que incluía as imagens mentais (Sheikh \& Jordan, 1983). Sendo assim, em contraste com o ocorrido na Europa, nenhuma linha de trabalho que fizesse extenso uso de procedimentos imagéticos surgiu antes dos anos '60. Isso independente de ela estar vinculada a uma grande corrente ou escola da psicologia, ou ser autônoma e menos difundida como as ora descritas. Em tempos mais recentes, entretanto, surgiram dois bons exemplos destas últimas: a 'psicoterapia eidética' e a programação neurolingüística'.

Quanto à primeira (e.g. Ahsen, 1991; Ahsen \& Lazarus, 1975; Cauthorne, 1985; Sheikh, 1978), o início de seu desenvolvimento aconteceu, na realidade, no Paquistão (cf. Sheikh \& Jordan, 1983), sendo posteriormente introduzida nos Estados Unidos. Seus mais conhecidos porta-vozes são Akhter Ahsen e Anees A. Sheikh, e baseia-se na evocação e manipulação de imagens eidéticas.

Tais imagens, caracterizadas por sua nitidez, detalhamento, e por serem relativamente fixas, como se fossem fotografias, podem ser de dois tipos: as evocadas pela apresentação de estímulos externos, caso em que ocorrem como se fossem imagens residuais particularmente prolongadas e nítidas de tais estímulos, e as provenientes da memória ou imaginação (Sheikh, 1978). A psicoterapia eidética lida especificamente com estas últimas, acreditando que correspondam a representações dos eventos que foram significativos na história de vida da pessoa.

E quanto à programação neurolingüística (e.g. Bandler, 1987; Bandler \& Grinder, 1982), talvez sua característica mais distintiva seja a de consistir em uma abordagem essencialmente pragmática, pouco preocupada com teorização. Ganhou projeção nos anos '80, 
por permitir, em alguns casos, uma remissão muito rápida de certos distúrbios de ordem emocional, tais como as fobias. Trabalha com imagens mentais dividindo-as em três modalidades básicas (visual, auditiva e cinestésica), supondo que cada pessoa tenha uma delas como predominante. Sua estratégia é identificar tal modalidade no cliente, acreditando que o terapeuta deva se adequar a essa modalidade para estabelecer um contato interpessoal eficiente.

A programação neurolingüística possui, igualmente, métodos para ajudar o indivíduo a intensificar imagens das modalidades que para ele sejam secundárias, julgando que isso possa encerrar valor terapêutico significativo. E desenvolveu ainda estratégias imagéticas de outros gêneros, um bom exemplo das quais é o o método que chama de 'ancorar'. Tal método vincula imagens internas a estímulos externos, sendo utilizado para que a pessoa reviva imagens de problemas passados associadas a outras de recursos internos que possibilitem a resolução desses problemas. A esse processo chamam 'mudança da história pessoal'.

Para finalizar, julgo importante deixar de lado os usos das imagens mentais já bem estabelecidos, para voltar-me um pouco para um novo veio, aparentemente bastante promissor, do trabalho terapêutico com imagens. Tal veio consiste na utilização dos sonhos lúcidos, que são aqueles em que o indivíduo sabe estar sonhando no momento em que o faz. Sonhos como esses ocorrem ocasionalmente, de maneira espontânea, com muitas pessoas. Entretanto, como essas ocorrências costumam ser muito esporádicas, sempre foi bastante difícil estudá-las sistematicamente. Associe-se a isso o fato de ter havido, por muitos anos, grande resistência de parte da maioria dos pesquisadores da área em encarar tal fenômeno como sendo realmente onírico. Argumentavam que consistiria, na realidade, em um estado intermediário entre sono e vigília, opondo-se à idéia de que poderia haver a consciência do estar sonhando durante um verdadeiro sonho (cf. LaBerge, 1990).

Esse estado de coisas só foi modificado com a formulação de estratégias de indução que permitiram programar, com razoável segurança, a ocorrência de tais sonhos em laboratório (cf. LaBerge, 1990). Além disso, houve ainda um outro fator que facilitou muito as investigações a respeito do assunto: a descoberta de que os movimentos dos olhos, que preenchem todos os períodos de sono REM ${ }^{19}$, estão associados aos movimentos do olhar do sonhador "dentro" do próprio sonho. LaBerge cita como exemplo disso uma pessoa que sonhou estar assistindo a uma partida de tênis de mesa, cujos olhos se movimentavam de um lado para outro, em sentido horizontal, como se realmente acompanhassem a bolinha sendo lançada de uma extremidade para a outra da mesa.

A partir daí não só se pôde começar a realizar estudos em laboratório, como estabelecer uma comunicação direta entre quem estivesse sonhando lucidamente e o pesquisador. Uma vez que, com certa experiência, o sonhador adquire um razoável controle sobre os acontecimentos de um sonho lúcido, o que inclui seu próprio comportamento, ele pode movimentar seus olhos como quiser. E isso permite que use códigos, baseados nesses movimentos, para fazer sinais para o investigador. Essa estratégia contribuiu, entre outras coisas, para comprovar definitivamente que a experiência do sonho lúcido é realmente onírica. Isso porque através dela o sonhador pode sinalizar que está sonhando lucidamente durante períodos de sono REM, que sabidamente são totalmente ocupados por sonhos.

O fenômeno do sonho lúcido e, mais que isso, os métodos eficientes criados para induzí-lo, abrem caminho para intervenções terapêuticas inovadoras (e.g. Evers \& Van de Wetering, 1993; Gackenback \& LaBerge, 1988). Podendo lidar com as imagens oníricas no momento em que elas são vivenciadas, e não apenas a posteriori, tais intervenções

19 Sono REM, ou sono paradoxal, é um dos estágios por que passa o sono ( a sigla 'REM' é composta pelas letras iniciais das palavras da expressão inglesa 'rapid eye movements'). 
encerram potenciais inauditos. Nelas é possível juntar a concretude, a profundidade e a carga emotiva privilegiadas das imagens dos sonhos, à capacidade de manipulação que se pode obter sobre as de vigília. Sendo assim, as possibilidades de trabalho permitidas por esse tipo de sonho podem vir a enriquecer significativamente o acervo de estratégias imagéticas da psicoterapia.

\section{A pesquisa científica sobre imagens mentais}

Como se pode perceber pelo que expus nas páginas anteriores, a utilização das imagens mentais é bastante ampla e diversificada, estendendo-se por inúmeros campos de atuação. E à semelhança do que ocorre com sua utilização, também a pesquisa sobre elas é bastante variada e visa inúmeros propósitos.

Antes de mais nada, é preciso esclarecer, porém, que nem todas as investigações relativas às imagens mentais as abordam do mesmo modo que o faço neste trabalho. Conforme já expliquei anteriormente, estou considerando como imagens mentais estritamente representações internas de teor quase-sensorial ou quase-perceptivo, portanto sempre passíveis de serem experienciadas conscientemente. Já certos pesquisadores, como muitos cognitivistas, as entendem não só enquanto acontecimentos dessa ordem, mas também como supostas estruturas cognitivas que não podem, em seu caráter mais essencial, ser percebidas pela consciência. Além disso, alguns outros, mesmo julgando o teor fenomênico das imagens importante, tendem mais a inferir sua ocorrência que a comprová-la cabalmente em seus estudos. E embora a questão sobre quanta evidência é preciso apresentar nesse sentido envolva controvérsia, parece-me factual que os investigadores que assim procedem correm um certo risco de tomarem outros fenômenos interiores por imagens mentais (cf. Pylyshyn, 1981; Richardson, 1983).

Como quer que seja, os tipos de pesquisadores descritos no parágrafo anterior são também figuras importantes no campo de investigação presentemente discutido. E apesar de nem sempre caracterizarem as imagens da mesma forma que o faço neste estudo, sua visão não chega a divergir da que adoto de tal forma que não apresente pontos em comum com a mesma. Portanto, creio que alguns representantes deles, apesar do acima exposto, devam ser aqui citados.

Passando agora para as pesquisas propriamente ditas, uma primeira área de investigação que se pode mencionar é a do funcionamento da memória. Um de seus grandes expoentes é Allan Paivio (e.g. Paivio 1971, 1986; Paivio \& Csapo, 1973). Em sua teoria, o aspecto experiencial das imagens é secundário. O mais essencial a respeito delas é que constituem, conforme já mencionei, um dos dois códigos que o ser humano utiliza para armazenar informações na memória, sendo o outro o verbal. Tal teoria foi desenvolvida para explicar os resultados de estudos que comparam a retenção de palavras concretas e abstratas com a de imagens. Neles foi observado que as imagens tendem a ser mais lembradas que os dois tipos de palavras e que, dentre estas, as concretas são melhor memorizadas. De acordo com a teoria em pauta, isso acontece porque, como também já expliquei, as imagens, assim como as palavras concretas, são armazenadas redundantemente nesses dois códigos. Por isso são melhor rememoradas que as palavras abstratas, que só podem ser armazenadas no código verbal.

Mais um exemplo de investigação relacionada ao estudo da memória é a de Marks (1973), sobre a relação entre a vivacidade da visualização de uma pessoa e sua memória visual. Nela, estudantes de psicologia e escolares de primeiro e segundo graus foram submetidos a um teste de vivacidade de visualização, e posteriormente comparados em termos da acuracidade com que lembravam de fotografias que lhes foram apresentadas. Os 
resultados, nos três experimentos realizados, indicaram que os melhores visualizadores de fato conseguiram, conforme o suposto, lembrar melhor das fotografias.

E ainda mais um estudo sobre memória que supostamente envolve imagens mentais é o de Anderson (1984). Neste caso, a autora trabalhou sobre o problema de discernir lembranças de comportamentos reais das de ações que foram apenas imaginadas (o que pode ser difícil para as pessoas em algumas ocasiões). E o fez através de tarefas que oscilavam entre reproduzir um desenho, imaginar-se reproduzindo-o e apenas observá-lo, constatando que houve mais dificuldade posterior de diferenciar a primeira da segunda tarefa que a primeira da terceira.

Outra linha de pesquisa que tem sido freqüentemente adotada é a referente à influência das imagens no processamento de informação visual. Para tanto tem-se estudado o que ocorre em certas tarefas de manipulação espacial que, acredita-se, envolvam também a manipulação de imagens. A esse respeito podem ser citados Shepard e Metzler (1971), Cooper e Shepard (1973, 1975), Shepard (1978), bem como Pinker e Finke (1980), com estudos sobre rotação mental, Kosslyn, Pinker, Smith e Schwartz (1979), que trabalharam com esquadrinhamento mental e ainda Finke e Shepard (1986), que analisaram o papel das imagens em diversas tarefas visuais (como identificação, comparação, localização, transformação e atenção visuais, além de controle visual-motor).

Autores como esses têm igualmente discutido, com base nos resultados das investigações descritas em seus trabalhos, as similaridades e diferenças existentes entre os processos de visualização e os de percepção visual propriamente dita (e.g. Finke \& Shepard, 1986; Shepard, 1978). Exemplo de um estudo específico a esse respeito é o de Chambers e Reisberg (1985), que relatam três experimentos sobre reversão de imagens mentais de figuras ambíguas, com o intuito de demonstrar diferenças entre os referidos processos.

Uma visão compreensiva sobre o assunto acima mencionado pode ser encontrada na resenha de Finke (1985). Nela, o autor divide as teorias existentes sobre relações entre imagens e percepção visual em estruturais, funcionais e interativas. As estruturais são as que propõem que as imagens apresentam as mesmas qualidades pictóricas e espaciais que os objetos físicos. As funcionais são as que defendem que a formação e a transformação de imagens mentais contribuem para o reconhecimento de objetos e a comparação entre os mesmos. $\mathrm{E}$ as interativas são aquelas segundo as quais as imagens contribuem diretamente para processos perceptivos em andamento.

Além do exposto acima, há também outras vertentes de pesquisa. Uma delas refere-se às características morfológicas ${ }^{20} \mathrm{e}$ de conteúdo das imagens, bem como à influência de certos fatores sobre tais características. Começando pelos trabalhos mais antigos, pode-se citar o de Rosemary Gordon (1949), que com o uso de um teste de controle sobre imagens por ela própria elaborado, investigou se tal controle estava associado ao grau de estereotipia das imagens de 118 universitários. E também merece menção o trabalho de Nise da Silveira. Com o emprego de recursos artísticos, essa estudiosa empreendeu, desde a década de 40' até não muito tempo atrás, extensa exploração das imagens interiores de psicóticos (cf. Silveira, 1982, 1992; Velloso, 1997).

Há igualmente o estudo de Reyher e Smeltzer (1968), que comparou, em 21 universitários, a capacidade das imagens de revelar material inconsciente com a da associação livre. Tal estudo concluiu que as imagens estavam ligadas a uma maior resposta galvânica da pele, uma maior participação de processos primários, mais representações diretas de impulsos e menos defesas psicológicas eficazes que a associação livre.

Do mesmo modo pode-se mencionar a investigação de Leite (1972), que pesquisou, através da análise de verbalizações noturnas e de relatos matutinos de sonhos,

20 O que estou aqui chamando de características morfológicas são as referentes a aspectos como vivacidade, nitidez e estabilidade das imagens. 
aspectos do conteúdo do material onírico. E ainda relacionados a sonhos, existem os trabalhos de Tomazella (1984) e Gallbach (1989). O primeiro autor investigou, através de procedimento de análise de conteúdo, sonhos de 79 crianças de seis anos de idade. Já a segunda, com base na teoria junguiana, realizou estudo sobre símbolos e temas presentes nos sonhos de mulheres que passavam por sua primeira gravidez.

Richardson e McAndrew (1990), por outro lado, observaram em 40 universitárias o efeito de três níveis de estimulação fótica, e do interesse que essas estudantes apresentavam por seus estados internos, sobre a complexidade de sua imaginação visual. E McKinney (1990) explorou o efeito de musica clássica sobre imagens espontâneas de 81 universitários. Verificou, em sua pesquisa, que aspectos como o tipo, a vivacidade e a freqüência das imagens não foram influenciados pela presença da música. Já a intensidade dos sentimentos associados às imagens aumentou significativamente com essa presença. Finalmente, Giambra e Grodsky (1991), usando três escalas de avaliação, investigaram se a freqüência, a nitidez e o realismo de imagens de devaneios estavam relacionados à idade das pessoas.

Certos autores têm pesquisado, igualmente, ligações entre a produção imagética e outras experiências psicológicas. Martinetti (1983), por exemplo, realizou uma investigação aplicando uma pequena bateria de testes de sua autoria a 90 estudantes de psicologia. Concluiu que a quantidade da produção de imagens em estado de vigília, e a atitude das pessoas frente aos processos imaginários em geral, estavam relacionadas ao número de sonhos de que se lembravam. Lyman e Waters (1989), por sua vez, estudaram a relação entre emoções e formação de imagens, analisando tipos e freqüências das imagens de 62 pessoas de 19 a 55 anos em 26 diferentes estados emocionais. Já Barret (1993), empregando escalas de mensuração, obteve indicativos de que a ocorrência de alucinações auditivas, em um grupo de pessoas tidas como normais, estava ligada à vivacidade de suas imagens, mas não ao controle que tais pessoas exerciam sobre elas.

Além disso, Goetz, Sadoski, Fatemi e Bush (1994) investigaram tanto as imagens espontâneas, como a reação emocional, de 56 universitários em resposta a artigos de jornal, observando relação significativa entre ambas as coisas. E Campos e Gonzalez (1994) exploraram a vinculação entre a competência para formar imagens mentais e habilidades acadêmicas, avaliando, através de testes, 1361 universitários de diferentes áreas.

Também é pertinente dar destaque a algumas pesquisas especificamente voltadas para o desenvolvimento, ou aperfeiçoamento, de provas psicométricas relativas a imagens. Tais provas possuem longa tradição, e são recurso importante para outras investigações, algumas das quais mencionadas acima (e.g. Barret, 1993; Campos \& Gonzalez, 1994; Giambra \& Grodsky 1991; Gordon, 1949). Já no século passado, Francis Galton (1883) formulou uma delas e, não muito depois, Betts (1909) estruturou seu questionário sobre vivacidade de imagens, cuja versão reduzida, elaborada por Sheehan (1967), é utilizada até hoje.

Entre as pesquisas propriamente ditas a respeito dessas provas figura, por exemplo, a de Sheehan (1967), que através da análise estatística dos resultados de 280 estudantes de psicologia no questionário de Betts (1909), estruturou a versão reduzida da prova. Dois outros investigadores que também podem ser mencionados são Campos e Pérez (1988). Tais pesquisadores aplicaram três questionários sobre imagens de diferentes autores (Farthing, Venturino \& Brown 1983; Isaac, 1983; Paivio, 1971) em 133 universitários, para verificar se havia relação entre as mensurações obtidas. E ainda Kihlstrom, Glisky, Peterson, Harvey et al. (1991) utilizaram três outros testes (os de Gordon, 1949, Marks, 1973, e Sheehan, 1967), que foram aplicados em mais de 2.000 universitários na busca de relações entre vivacidade e controle de imagens. 
Outro autor digno de nota é Martinetti (1989), que apresentou em seu estudo a padronização e a análise fatorial dos resultados das três escalas que compõem sua própria bateria de testes, sendo duas delas referentes a imagens. Da mesma forma, Gissurarson (1992) pesquisou, através de aplicação em 160 pessoas de 16 a 82 anos, uma nova escala para medir imagens auditivas. Observou também que seus resultados estavam correlacionados com os de um teste de nitidez e outro de controle de visualizações, concluindo que existe uma capacidade imagética genérica responsável, pelo menos, pelas imagens visuais e auditivas. E Atienza, Balaguer e Garcia Merita (1994) realizaram uma análise fatorial dos resultados de 110 pessoas de 14 a 31 anos em um teste sobre imagens de movimento, concluindo que os ítens referentes a imagens visuais e cinestésicas relacionavam-se a duas variáveis diferentes.

A par dos tipos de investigação mencionados nas páginas anteriores, outro gênero de pesquisa que também é algumas vezes empreendido relaciona-se ao fenômeno da sinestesia. Tal fenômeno consiste na evocação de imagens de uma determinada modalidade sensorial em resposta a estímulos de outra modalidade. Um exemplo desse tipo de investigação pode ser encontrado em Rader e Tellegen (1987), que procuraram averiguar relações entre a sinestesia e aspectos do funcionamento intelectual e da personalidade. Para tanto, aplicaram testes de sinestesia, personalidade e inteligência em 374 pessoas. Como resultado, não constataram quaisquer relações entre as medidas de vivacidade das imagens sinestésicas e as de inteligência e disfunções de personalidade, mas verificaram uma relação moderada entre as mensurações de vivacidade e a de tendência a apreciar e se envolver em experiências imaginárias.

E ainda é importante mencionar algumas pesquisas realizadas com o intuito de avaliar os resultados da utilização de várias práticas imagéticas. Na medicina, por exemplo, vêm sendo realizadas, há vários anos, investigações relativas ao já citado uso de imagens no combate ao câncer. Os resultados desses estudos têm sido bastante animadores, havendo alguns casos em que os procedimentos imagéticos revelaram-se mais eficientes, em termos de remissão da moléstia, que a terapêutica ortodoxa (cf. Samuels \& Samuels, 1975). Além disso, também pode-se citar o trabalho de Andrews e Hall (1990). Tais autores investigaram, junto a sete voluntários com idade entre 16 e 66 anos, o emprego de relaxamento, associado a procedimentos imagéticos, para o controle de estomatite aftosa crônica. E observaram que o método de intervenção adotado levou a um decréscimo significativo no número de recorrências do problema.

Além de pesquisas na área médica, também existem estudos no âmbito das práticas esportivas. Dentre as diversas estratégias imagéticas adotadas para o aperfeiçoamento em vários esportes, algumas têm sido avaliadas através de estudos razoavelmente cuidadosos. Tais estudos geralmente não contam com a participação de muitos indivíduos, e muitas vezes não utilizam grupo de controle. Não obstante, os métodos de avaliação de habilidade que empregam costumam apresentar certa consistência, o que merece um certo crédito. Nessa categoria se enquandra, por exemplo, o experimento de Kendall, Hrycaiko, Martin e Kendall (1990). Tais autores conduziram, com quatro universitárias de um time de basquetebol, uma estratégia de intervenção que envolvia o ensaio imagético de situações competitivas. E a partir de análise de vídeoteipes concluíram que tal estratégia foi eficaz em melhorar o desempenho das atletas durante os jogos. Também pode-se mencionar, dentro do mesmo tipo de investigação, o estudo de caso realizado por Savoy (1993). Tal estudo objetivou avaliar os progressos obtidos por uma jogadora de basquete, durante uma temporada, com a introdução de um programa de treinamento mental que incluía o uso de imagens. Seus resultados, mais uma vez, indicaram o sucesso da estratégia de intervenção. E o leitor interessado poderá encontrar ainda várias outras investigações mais antigas, voltadas para diversos esportes, no já citado trabalho de Suinn (1983). 
Agora no que toca à psicoterapia, começando pelos trabalhos mais antigos, podem ser citadas as pesquisas sobre procedimentos imagéticos da psicologia comportamental (dessensibilização sistemática, sensibilização encoberta, etc.). Tais pesquisas, geralmente bem planejadas e envolvendo verificações o mais objetivas possível, já são bastante conhecidas, de modo que não me deterei sobre suas particularidades. O leitor que desejar maiores informações a seu respeito poderá encontrá-las em trabalhos como os de Cautela, (1967), Bandura (1969) e Lang (1977).

Há também estudos mais recentes, que abrangem outros métodos de intervenção imagética. Wolff (1981), por exemplo, explorou, analisando casos clínicos, o emprego de sonhos em psicoterapia psicodramática. E Lima (1990) investigou, através de análise de conteúdo de trechos do relato de um trabalho vivencial intensivo, o método de trabalho com sonhos que Fritz Perls elaborou para uso em gestalt-terapia.

Além deles, Koziey e Andersen (1990), bem como Baider, Uziely e Kaplan De Nour (1994), realizaram investigações a respeito de fantasia dirigida. Na primeira dessas investigações, o procedimento imagético foi considerado eficaz para explorar padrões vivenciais de nove universitários engajados num seminário de comunicação interpessoal. E na segunda, uma estratégia que associava fantasia dirigida a relaxamento foi empregada para auxiliar pacientes com câncer a lidarem com questões psicológicas associadas à doença. Neste caso, os 86 pacientes que terminaram o tratamento melhoraram seus resultados em duas das três escalas de medida empregadas na avaliação, e 58 mantiveram tais melhoras durante um follow up de seis meses.

Também merecem ser mencionados Abraham, Neundorfer e colaboradores (Abraham, Neundorfer \& Currie, 1992; Abraham, Neundorfer \& Terris, 1993). Tais autores avaliaram os efeitos de estratégia grupal, baseada em imagens visuais, sobre distúrbios cognitivos e depressivos de idosos (71 a 97 anos) residentes em instituição. Seus resultados levaram à conclusão de que a estratégia adotada gerou melhorias no desempenho cognitivo dos participantes, mas não progressos em termos de depressão, desamparo e satisfação com a vida.

E ainda pode-se citar os trabalhos de Rider e Kibler (1990) e Stanton (1992). O primeiro deles mostrou indícios positivos a respeito do uso de imagens dirigidas, associado a música, sobre o comportamento de 13 indivíduos com artrite e lúpus eritematoso. Já no segundo, utilizou-se uma estratégia hipnótico-imagética visando reduzir a ansiedade, e melhorar as notas nos exames escolares, de 40 adolescentes de sétima série. Os resultados dos adolescentes, tanto numa escala de ansiedade em provas e exames, como num exame escolar ocorrido após o emprego da estratégia avaliada, indicaram o sucesso do procedimento de intervenção.

Por fim, é convém também incluir, no referente à psicoterapia, alguns estudos já citados com relação a outros assuntos, mas não vinculados à avaliação de práticas imagéticas. Isso porque, embora de maneira um pouco menos direta, não deixam de ser de importância evidente para o tema presentemente discutido. Esse é o caso do trabalho de Reyher e Smeltzer (1968), que enfocou um aspecto das imagens de grande interesse clínico, qual seja sua potencialidade para revelar material inconsciente. Também é o caso da investigação de McKinney (1990), que obteve indicativos de que a música pode aumentar significativamente a intensidade de sentimentos associados a imagens, o que pode ter grande valor para a situação terapêutica. E, finalmente, pode-se dizer o mesmo da pesquisa de Lyman e Waters (1989), uma vez que foi igualmente dirigida para uma questão clinicamente relevante, qual seja a relação entre emoções e produção imagética.

Para concluir, cabe salientar que as pesquisas sobre imagens mentais, apesar de não serem raras e de sua variedade, são ainda demasiado poucas em face da complexidade 
dessas imagens, da grande quantidade de áreas em que ocorre sua aplicação, e da diversidade dessas aplicações. Sendo assim, há muito ainda o que investigar, e é importante que recursos e talento continuem a ser mobilizados para tanto. Se não simplesmente para o desenvolvimento do conhecimento científico, pelo fato de que as estratégias imagéticas têm mostrado grande potencial em muitas áreas de atuação. E esse potencial certamente poderá ser bastante ampliado com o aumento dos conhecimentos tanto sobre tais estratégias como sobre as imagens em si mesmas.

\section{Objetivos desta pesquisa}

principais:

Os propósitos centrais desta investigação nortearam-se por três razões

- Haja vista a diversidade e o grande número de empregos psicoterapêuticos de imagens mentais, até o momento são insuficientes os trabalhos que avaliam, precisa e fidedignamente, os resultados de muitos desses empregos.

- As estratégias terapêuticas imagéticas parecem apresentar resultados oscilantes. Em algumas ocasiões seus benefícios afiguram-se como bastante significativos e, em outras, como moderados ou mesmo inexistentes.

- Há uma série de fatores ainda não suficientemente explorados que podem estar associados ao maior ou menor sucesso na utilização de tais estratégias. Além da perícia do profissional, da situação de vida da pessoa atendida e do teor do relacionamento terapeutacliente, freqüentemente levados em conta na psicoterapia, outros pontos devem ser considerados.

Um deles, que parece relativamente obvio, é a atitude do cliente com respeito aos processos imaginários e, por conseguinte, frente às imagens mentais. Enquanto há pessoas com uma orientação concreta e racionalista que não vêem proveito em desenvolver a imaginação, há outras que valorizam muito seu cultivo. Dessa forma, é bastante coerente supor que as primeiras mostrar-se-ão mais refratárias a intervenções imagéticas que as últimas, o que pode ser decisivo num processo terapêutico.

E no referente a exercícios em que os clientes são instruídos a deliberadamente evocarem imagens mentais, é igualmente plausível supor, como vários autores (e.g. Bandler \& Grinder, 1982; Lusebrink, 1990; Richardson, 1983), que as pessoas capazes de fazerem-no com maior vivacidade se envolvam mais profundamente com a situação. E que com isso tenham melhores chances de bons resultados.

Ainda é possível imaginar, à semelhança dos mesmos Richardson (1983) e Lusebrink (1990), que um bom controle sobre as imagens, ou seja, uma boa capacidade de manipulá-las voluntariamente, permita mais desenvoltura na realização de tais exercícios, o que eventualmente pode aumentar a eficiência dos mesmos.

Ademais, o mesmo pode ser dito do quanto uma pessoa gera, de maneira espontânea, imagens existencialmente significativas, da criatividade de sua imaginação e de vários outros fatores que não foram aqui mencionados.

Tendo em mente o que acabei de expor, minha intenção primordial foi investigar, de maneira sistemática e o mais objetiva que me fosse possível, o seguinte:

- Se um determinado tipo de atendimento psicoterapêutico, envolvendo ampla utilização de exercícios voltados para a evocação deliberada de imagens mentais, apresentaria resultados positivos. 
- Se os três primeiros aspectos supracitados do comportamento relativo a imagens mentais da clientela de tal atendimento (atitude com respeito à imaginação, bem como vivacidade e controle das imagens) poderiam influenciar o grau de sucesso dessa clientela no mesmo, contribuindo para a oscilação de resultados que se observa em estratégias congêneres.

E minhas hipóteses iniciais foram, mais especificamente:

- O tratamento psicológico utilizado seria bem sucedido.

- E o seria, em maior grau, com as pessoas que, previamente, apresentassem melhores índices de atitude frente à imaginação, como também de vivacidade e controle das imagens, que com as que apresentassem piores índices a esse respeito.

Em síntese, este trabalho buscou avaliar a eficácia de um determinado tipo de emprego de imagens mentais em psicoterapia, e a influência de certos aspectos do comportamento do cliente frente a essas imagens sobre tal eficácia. 